\title{
Fatty Acids, Antioxidants and Physical Activity in Brain Aging
}

\author{
Hércules Rezende Freitas ${ }^{1, *}$ (D), Gustavo da Costa Ferreira ${ }^{1,2}$, Isis Hara Trevenzoli ${ }^{3}$, \\ Karen de Jesus Oliveira ${ }^{4}$ and Ricardo Augusto de Melo Reis ${ }^{1}$ \\ 1 Laboratory of Neurochemistry, Institute of Biophysics Carlos Chagas Filho, \\ Universidade Federal do Rio de Janeiro, Rio de Janeiro 21941-901, Brazil; \\ gustavolhe@gmail.com (G.d.C.F.); ramreis@biof.ufrj.br (R.A.d.M.R.) \\ 2 Laboratory of Neuroenergetics and Inborn Errors of Metabolism, Institute of Medical Biochemistry \\ Leopoldo de Meis, Universidade Federal do Rio de Janeiro, Rio de Janeiro 21941-901, Brazil \\ 3 Laboratory of Molecular Endocrinology, Institute of Biophysics Carlos Chagas Filho, \\ Universidade Federal do Rio de Janeiro, Rio de Janeiro 21941-901, Brazil; haraisis@biof.ufrj.br \\ 4 Laboratory of Endocrine Physiology and Metabology, Biomedical Institute, \\ Universidade Federal Fluminense, Niterói 24210-130, Brazil; karenoliveira@id.uff.br \\ * Correspondence: freitashr@biof.ufrj.br; Tel.: +55-(21)-3938-6594
}

Received: 1 October 2017; Accepted: 14 November 2017; Published: 20 November 2017

\begin{abstract}
Polyunsaturated fatty acids and antioxidants are important mediators in the central nervous system. Lipid derivatives may control the production of proinflammatory agents and regulate NF- $\mathrm{kB}$ activity, microglial activation, and fatty acid oxidation; on the other hand, antioxidants, such as glutathione and ascorbate, have been shown to signal through transmitter receptors and protect against acute and chronic oxidative stress, modulating the activity of different signaling pathways. Several authors have investigated the role of these nutrients in the brains of the young and the aged in degenerative diseases such as Alzheimer's and Parkinson's, and during brain aging due to adiposityand physical inactivity-mediated metabolic disturbances, chronic inflammation, and oxidative stress. Through a literature review, we aimed to highlight recent data on the role of adiposity, fatty acids, antioxidants, and physical inactivity in the pathophysiology of the brain and in the molecular mechanisms of senescence. Data indicate the complexity and necessity of endogenous/dietary antioxidants for the maintenance of redox status and the control of neuroglial signaling under stress. Recent studies also indicate that omega- 3 and -6 fatty acids act in a competitive manner to generate mediators for energy metabolism, influencing feeding behavior, neural plasticity, and memory during aging. Finding pharmacological or dietary resources that mitigate or prevent neurodegenerative affections continues to be a great challenge and requires additional effort from researchers, clinicians, and nutritionists in the field.
\end{abstract}

Keywords: essential fatty acids; ascorbic acid; glutathione; aging; senescence; nervous system; growth factors; neuroprotection; docosahexaenoic acid; inflammation

\section{Introduction}

Throughout the 20th century, evidence-based medical knowledge has allowed for a significant increase in life expectancy, especially in well-developed countries. Epidemiological data from 1900 (United States and United Kingdom) indicate that $50 \%$ of the population lived approximately until 50 years old, while in the 1990's, half of the population lived until 80 years old [1]. The world health organization (WHO) estimates that there was a global increase of 5.0 years in life expectancy between 2000 and 2015, with an even larger increase of 9.4 years observed in Africa (WHO, 2016). The aging process is, however, permissive for the development of several degenerative disorders and infectious 
diseases, which are strongly influenced by nutritional imbalances, inflammation, metabolic exhaustion, and the natural process of cellular senescence [2].

Insufficient ingestion and/or deficient absorption of essential nutrients deeply affects the health conditions of elderly individuals. Frangeskou and coworkers explored the impact of dehydration as an extenuating factor for public expenses with health services, increasing mortality, hospital readmission, and period of stay under medical/hospital care [3]. Digestion and absorption of nutrients is normally deficient in the elderly, as compared with younger individuals. In a recent study, it was shown that essential and branched-chain amino acids reach peak blood levels within $1 \mathrm{~h}$ after young individuals (20-25 years old) receive a protein-rich meal, while the same peak concentrations were reached only $3 \mathrm{~h}$ post-meal for an elderly (60-75 years old) group [4].

The prevalence of malnutrition, weakness, and related disabilities are also relevant factors and may encompass a large portion of the aged population, mainly those institutionalized (hospitalized) and resident of non-developed/developing countries [5]. In a cross-sectional Brazilian epidemiological study with elderly individuals ( $\geq 60$ years old), anemia index, hemoglobin concentration, and population frailty were intrinsically related, indicating that low levels of hemoglobin are associated with a greater number of frailty indicators (Fried phenotype criteria) [6].

On the other hand, the consumption of Western diets is increasing worldwide, and these diets are characterized by high lipid consumption (mainly saturated fatty acids, or SFA) and refined carbohydrate consumption with low ingestion of vegetables, and they have been associated with the development of obesity, cardiovascular disorders, cancer, and diabetes [7]. Loss of endothelial homeostasis during aging, for example, strongly depends on nutritional factors, oxidative stress, and inflammation. Dietetic interventions in elderly people are, however, hardened by cognitive impairment and loss of mobility, which limits their autonomy for preparing complex meals, as well as for chewing and digesting food [8]. Regulation of the circadian cycle and a decrease in dietetic calories content has been shown to effectively favor longevity in several in vivo models [9].

In emerging countries, such as Asian and Latin-American nations, it is possible to observe a marked effect of nutritional transition, parallel to the accelerated expansion of urban areas, which incorporates deleterious dietary habits in the population [10]. This factor introduces a deep epidemiological concern, since modifications in feeding habits and obesity are strong indicators of health risk, such as high blood cholesterol, pre-diabetes, hypertension, asthma, arthritis, and bad or regular self-reported health condition [11]. Weight variations affect the well-being of elderly patients, a determinant factor for survival within this group [12].

Depression may also be related to the development of obesity [13], and obesity itself is significantly associated with alcohol abuse and depression, mainly in adult female individuals or highly obese subjects $[14,15]$. Current dietetic approaches rely on providing balanced amounts of energy, and macro and micronutrients; other therapies, such as correction of the gut microbiome and global intestine health, await further clinical evidence [16]. Here, we explore post-transitional aspects of modern feeding, especially the intake of fatty acids and antioxidants, which greatly relate to the process of brain aging, one of the pillars in generalized senescence.

\section{Senescence of the Nervous System}

Many disabling central nervous system (CNS) symptoms and diseases are highly associated with the aging process, including cerebrovascular disease, Alzheimer's disease (AD), and Parkinson's disease (PD), as well as decline in attention and memory $[17,18]$. Despite the current medical advances to extend lifespan, untangling the precise metabolic interactions involved in the process of neural aging continues to be a challenge. Both endogenous and environmental factors have been postulated to trigger cellular senescence, including genetic alterations (DNA damage and shortening of telomeres) and non-physiological activity of transcription factors [19,20], accumulation of aberrant proteins [21], excitotoxicity [22], oxidative damage, mitochondrial dysfunction [23,24], and others. Here we focus 
mainly on stress-induced senescence, aiming to pinpoint the aspects of aging in the context of food behavior and physical activity in modern (urban) societies.

It has been shown that the disturbances in brain synaptic circuitry that occur, especially in the hippocampus and pre-frontal cortex during aging, might promote relevant cognitive decline [25]. Oxidative damage accumulates with age and is potentially harmful to many mitochondrial functions. Contributing factors include decreased membrane fluidity and the intrinsic rate of proton leakage across the inner mitochondrial membrane [26]. Previous reports showed that mitochondria are chronically depolarized in senescent neural cells; this includes an age-dependent decrease in mitochondrial membrane potential in cerebellar neurons from brain slices [27] and in cultured basal forebrain neurons [28]. Brain mitochondria from senescent rats present damaged mitochondrial complex I, which may be related to the increase of Bax/Bcl-2 cascade (apoptosis regulator) observed in these mitochondria [29]. It has also been shown in rats and humans that mitochondria from senescent subjects are larger than in younger subjects, but fewer in number [30-32]. On the one hand, the total volume of the cell occupied by mitochondria is virtually unaltered in young and older subjects, and these larger mitochondria do not feature the same bioenergetic capability [32,33]. Potential consequences of mitochondrial chronic depolarization include impaired ATP synthesis and redox homeostasis, as well as disruption of the calcium gradient across the mitochondrial membrane with subsequent impairment of calcium stores or increase in the threshold necessary to trigger cation uptake [34]. Thus, changes in the metabolic status would greatly impair the fuel reserves of the neural cells and consequently make them less capable to respond to injury. In the context of the cognitive impairment of aged subjects, the linchpin seems to be the activity of the fast-spiking interneurons [35], which have high metabolic demands and thus are more susceptible to metabolic dysfunction [36].

Accumulated data indicate that different mechanisms, including gradual dysfunction of respiratory chain complexes involved in the electron transfer (mainly complexes I and IV), flaws in compensatory mechanisms, inaccurate gene expression, and increased number of mitochondrial DNA (mtDNA) damage, may influence the progression of AD [37]. Blood glucose homeostasis and several associated metabolic pathways appear to be altered in the brain of AD patients; however, these manifestations may be consequence of the progression of aging and disease, which undermine synapses and attenuate the demand for glucose, further contributing to the functional and progressive decline of cerebral functions [38].

One of the main regulators of growth and survival in adverse environmental conditions, the mammalian target of rapamycin (mTOR), is a catalytic subunit of two distinct complexes known as mTOR1 and mTOR2 complexes (mTORC1 and mTORC2, respectively) [39]. The intrinsic communication of mTOR complexes (mainly mTORC1) with the metabolic control of glycogenesis and lipogenesis is essential to maintain central homeostasis [39,40], since neural cells are highly dependent on the continued supply of glucose and other energy substrates (e.g., ketone bodies) to maintain the ATP / AMP ratio. This dynamic allows for the correct regulation of autophagy systems, essential for the clearance of malfunctioning organelles and misfolded proteins, which have been found to be dysregulated in central diseases such as $\mathrm{AD}$ [41].

Nutritional profile of older individuals seems to be important to the progression of several pathological conditions affecting CNS. It has been reported that the occurrence of disabilities and signals of fatigue are significantly correlated to diet deficiency of folate (i.e., vitamin B9) and magnesium in patients with multiple sclerosis (MS) [42]. The onset of preclinical indicators for AD suggest that the availability of micronutrients and fatty acids, especially docosahexaenoic acid (DHA), is gradually restricted and follows the progression of the disease in aged subjects. Protein-energy nutritional status is also aggravated in $\mathrm{AD}$, but it usually parallels the symptoms of cognitive impairment. Nutritional strategies that combine key nutrients for the formation and maintenance of synaptic integrity have been used primarily to prevent loss or impairment of memory in AD patients [43]. In vivo restriction in the supply of nutrients during pre- and post-natal periods causes metabolic changes to the blood-brain barrier (BBB), inducing cognitive disorders and predisposition to AD [44]. 
These findings underscore an intrinsic relationship between adequate supply of essential nutrients, especially fatty acids and antioxidants, and maintenance of central homeostasis during aging.

\section{Adiposity, Neuroinflammation and Senescence}

The hypothalamus is a key region in the CNS controlling energy homeostasis, and it is sensitive to metabolic signals, such as fatty acids and glucose, and several hormonal signals derived from peripheral tissues such as gut, pancreas, and adipose tissue. Increased adiposity or obesity are frequently features in senescent subjects. Both aging and obesity can affect the central regulation of systemic homeostasis, increasing the risk of developing AD, insulin resistance, diabetes mellitus, and cardiovascular and cerebrovascular diseases. However, because these two metabolic conditions commonly coexist, it is difficult to distinguish the relative contribution of each one to the disease progression. Neuroinflammation seems to be a common mechanism by which these conditions independently and interactively impair neurogenesis, neural stem cell survival and differentiation, and promote aging-related cognitive decline and neurodegenerative diseases [45,46].

Neuroinflammation is associated with BBB breakdown and neurodegeneration. Because obesity is related to a persistent pro-inflammatory state [47], plasma-derived deleterious factors such as lipopolysaccharides (LPS) and SFA can pass through the damaged BBB to induce neuroinflammation. In fact, serum derived from aged mice or aged high-fat fed mice produces significant microglia activation, with increased reactive oxygen species (ROS) production and cytokine expression in the hippocampus [48]. On the other hand, Nlrp3 inflammasome knockout mice show decreased metabolic and inflammatory markers in peripheral and central tissues, improved functional cognitive decline during aging, and extended lifespan [49]. In the hypothalamus, both aging and over nutrition increase the proinflammatory axis comprising I $\mathrm{KB}$ kinase- $\beta$ (IKK $\beta)$ and its downstream nuclear transcription factor NF- $\kappa B$ (IKK $\beta / N F-\kappa B$ signaling). Hypothalamic inflammation decreases satiety response to insulin and to the adipocyte-derived hormone leptin, which can contribute to positive energy balance and development of obesity [50]. Several cellular mechanisms contribute to hypothalamic aging in healthy and obese individuals, including genomic instability, telomere shortening (replicative senescence), epigenetic mechanisms, stem-cell depletion, endoplasmic reticulum stress, loss of proteostasis, and autophagy [51].

In diet-induced obesity, white adipose tissue dysfunction is the primary source of altered levels of circulating free fatty acids, several hormones called adipokines, and proinflammatory cytokines. White adipose tissue depots are in the subcutaneous and visceral compartments. In addition to controlling fuel accumulation, the adipose tissue is an important endocrine organ that releases adipokines, which allow for its effective interaction with several other tissues including CNS, liver, muscle, and pancreas to regulate energy metabolism in an efficient and integrated manner in healthy individuals [52].

White adipose tissue depots present a complex cell composition, including the main cell type, adipocytes, but also pre-adipocytes, fibroblasts, mesenchymal cells, immune cells (macrophages, $\mathrm{T}$ cells and others), endothelial cells, and smooth muscle cells [52,53]. Adipose tissue cellularity can present alterations depending on whether their metabolic status is lean or obese. In lean adipose tissue, resident or recruited macrophages are mostly M2-anti-inflammatory that produce TGF- $\beta$ (transforming growth factor beta), IL-10 (interleukin 10), CCL17, 18, 22, and 24 (CC chemokine ligands). In adipose tissue from obese subjects the main macrophage population is the M1-proinflammatory cells that produce mainly IL-6, TNF- $\alpha$ (tumor necrosis factor alpha), IL-1 $\beta$, and IFN- $\gamma$ (interferon gamma) [54]. Therefore, these proinflammatory markers produced by adipose tissue may cross BBB to trigger neuroinflammation and brain aging.

Leptin is an important hormone released by adipocytes involved in white adipose tissue and brain crosstalk. Leptin production positively correlates with fat mass. Therefore, obese individuals present with hyperleptinemia, which causes differential modulation of food intake, glucose, and fat metabolism through interaction with hypothalamic receptors [55]. Leptin acts mainly on the arcuate 
hypothalamic nucleus (Arc), activating anorexigenic neurons that express proopiomelanocortin and cocaine/amphetamine-related transcript (POMC/CART neurons), thus inhibiting orexigenic neurons that express the neurotransmitters neuropeptide $\mathrm{Y}$ and agouti-related protein (NPY/AgRP neurons) [56,57]. In lean individuals, leptin action results in decreased food intake and increased energy expenditure to control fat mass expansion by a negative feedback loop. However, in obese individuals, hyperleptinemia is commonly associated with hypothalamic leptin resistance and a progressive increase of adiposity [58].

In experimental models of aging, hypothalamic regulation of lifespan has been suggested as it was demonstrated an increased hypothalamic expression of NF- $\mathrm{KB}$ pathway in experimental models of advanced age, and that inhibition of this pathway delays aging and extends lifespan of rodents $[59,60]$. In old rats, brain inflammation induced by LPS has been associated with increased peripheral inflammatory markers and hyperleptinemia, while treatment with anti-leptin serum partially reverses brain inflammation, highlighting the crucial role of leptin as a mediator of brain inflammation in aging. As indicated, dietetic interventions may not only ameliorate metabolic disruption (such as insulin sensitivity), but also regulate the influence of peripheral hormones and mediators in brain "inflammaging", a process where inflammation is strongly correlated, and possibly causal, to aging phenomena [61].

In humans, the relationship between leptin and cognition in the elderly population is controversial and deserves careful interpretation. While mid-life obesity and systemic metabolic changes, such as high leptin circulating levels, are risk factors in the development of dementia, low plasma leptin levels later in life are associated with worsening cognitive decline and increased risk of developing AD $[62,63]$. This controversial pattern seems to be age-dependent. Possibly, higher levels of leptin in mid-life could trigger initial deleterious mechanisms in the brain, predisposing it to aging-related diseases, and after the actual development of cognitive impairment in older individuals, changes in the whole body energy metabolism can result in weight loss and, consequently, lower leptin levels.

In healthy elderly subjects, plasma leptin levels are positively correlated with grey matter volume of several brain regions, including the hippocampus [64], and inversely correlated with aging-related cognitive decline [65]. In a prospective study of the Framingham original cohort, circulating leptin levels were associated with reduced incidence of dementia and AD in asymptomatic older adults [66]. Therefore, these studies suggest a protective effect of leptin on brain function. On the contrary, mild cognitive impairment was positively correlated with serum leptin and IL- $1 \beta$ levels, and inversely correlated with adiponectin in elderly population [67]. Additionally, in elderly individuals included in the Alzheimer's Disease Neuroimaging Initiative (ADNI) study, higher leptin levels were associated with deficits in frontal, parietal, temporal and occipital lobes, brainstem, and the cerebellum [68].

In contrast to obesity and hyperleptinemia, caloric restriction is another energetic challenge that can modulate adiposity, brain function, and lifespan. From the evolutionary perspective, the brain is a unique organ that presents optimal cognitive function performance under hunger/food scarcity conditions [69]. Caloric restriction can optimize brain function throughout several molecular and cellular mechanisms that include modulation of synaptic activity, brain-derived neurotrophic factor (BDNF) signaling, mitochondrial biogenesis, DNA repair, protein homeostasis, and reduced inflammation [70]. Sirtuins are important mediators of the brain metabolic adaptation during caloric restriction. Sirtuins (SIRT1-SIRT7) are enzymes commonly known as NAD+-dependent histone deacetylases (HDAC). However, in addition to controlling gene expression by chromatin remodeling, sirtuins can regulate a variety of cellular functions by modulating the activity of kinases, transcription factors, and other molecular targets [71]. Brain content of SIRT1 increases in response to caloric restriction and is involved in several brain and behavioral adaptations in mice [72,73]. Activation of SIRT1 has been associated with a protective role in neuroinflammation induced by LPS or IL1- $\beta$ in vivo and in vitro models, as well as in neuroinflammation associated with AD. Interestingly, these studies show that SIRT1 activation may be also induced by dietary components such as resveratrol (a potent 
antioxidant polyphenol), and eicosapentaenoic acid (EPA) and docosahexaenoic acid (DHA), the major $\omega-3$ polyunsaturated fatty acids (PUFAs) from fish oil [74,75].

\section{Fatty Acids}

PUFAs, especially DHA, play an essential role in the maintenance of central and peripheral metabolism. DHA is produced by desaturation and elongation of $\alpha$-linolenic acid (ALA), which is considered essential in the diet, since mammals are unable to biosynthesize DHA and EPA from precursors with shorter hydrocarbon chains [76]. Humans are required to intake dietary ALA present in leafy vegetables and oil, together with EPA and DHA from fish oil [77]. ALA, DHA, and EPA (i.e., omega-3) should be maintained at appropriate levels in the diet, since the quantitative ratio between linoleic acid (LA, i.e., omega-6) and ALA is critical to control the production of arachidonic acid (ARA) and pro-inflammatory mediators (e.g., eicosanoids), which play an important role in the progression of cardiovascular diseases, diabetes, and brain disorders [78].

Cerebrovascular diseases and neurodegenerative processes are highly dependent on the stability of central blood. The proper functioning of reperfusion systems attenuates cell death and prevents stroke episodes, resulting in less cognitive impairment over time $[79,80]$. Maintenance of the connective brain structure in patients with $\mathrm{AD}$ is one of the major challenges in preserving memory and associated functions; changes such as severe hippocampal atrophy and increased lesions in white matter are, at least, prevented by interventions in which PUFAs-enriched diets are provided, especially DHA and EPA. In addition, patients undergoing diets rich in these fatty acids are less likely to develop neurodegenerative processes or functional and cognitive loss toward the progression of the disease [81].

In a recent study, senescent rodents depleted of omega-3 had greater dysfunction in glutamatergic synapses and 30\% lower uptake of glutamate in astroglia from CA1 hippocampal area [82]. Studies using imaging methods have shown that, even in individuals with normal cognition, fish oil supplementation is positively associated with a greater average volume of the hippocampus, cingulate cortex, and orbitofrontal areas. Fish oil supplementation was also related to higher scores on standardized cognitive tests. Presence of the ApoE4 allele seems to be a determining factor in the outcome of clinical trials with DHA, since patients without this allele present better results from dietary and pharmacological interventions using omega-3 [83,84].

Omega-3 fatty acids decrease the synthesis of proinflammatory lipid mediators produced by the omega- 6 and ARA metabolism in a competitive manner. Omega- 3 acts as endogenous ligand of the transcriptional factors peroxisome proliferator-activated receptors (PPAR- $\gamma$ and $\alpha$ ) that attenuate the activity of NF- $\mathrm{kB}$ mediated inflammatory pathways (e.g., cycloxygenase-2, TNF, IL-1) and modulate the mechanism of fatty acid oxidation, peroxisome proliferation, sensitization to insulin, and adipocyte differentiation, a potential therapeutic target in the treatment of dyslipidemia [85,86]. In the brain, PPAR- $\gamma$ participates in many aspects of microglial activation, myelination, heat shock protein (HSP) response, cell death, production of TNF- $\alpha$, and inhibition of Activator Protein 1 (AP-1) and NF-KB, besides reducing the synthesis of nitric oxide (NO) and prostaglandin E2 (PGE2). Therefore, PPAR- $\gamma$ plays a critical anti-inflammatory role in diseases such as Parkinson's disease, multiple sclerosis, and AD $[87,88]$. PPAR- $\gamma$ has also been demonstrated to be effective in preventing intracerebral ischemic damage, especially in patients with associated morbidities, such as type II diabetes [89].

Afshordel and colleagues (2015) have recently explored another central mechanism of DHA, which can be converted to neuroprotectin D-1 (NPD-1), an unesterified derivative with neuroprotective properties. Authors showed that fish oil supplementation in aged rodents can raise levels of unesterified DHA and NPD-1-like metabolites in parallel to increased Bcl-2 levels in the brain, suggesting that EPA and/or DHA contribute to the control of apoptotic mechanisms and mitochondrial function [90].

Omega 3 fatty acids play an important role in preventing chronic injuries in peripheral and central metabolism, especially for patients undergoing Western diets. In fact, recent data on in vivo models suggest that supplementation of these fatty acids can prevent cognitive decline, promote hippocampal 
protection, and neuroplasticity [91]. The balance between saturated and unsaturated fatty acids may control features of the peripheral metabolism. Kaplan and Greenwood discuss the importance of SFA consumption on the control of feeding behavior in animal models, highlighting its negative influence on the hepatic metabolism of glucose, which in turn regulates its availability to the brain, where it can control the production of neurotransmitters, trophic factors, feeding behavior, and general cognitive performance [92].

The benefits of consuming low-calorie meals, fibers, and omega-3 rich foods are well supported by the literature [60,77-82]. Eating patterns, however, depend on the individual's ability to control dietary intake. For subjects undergoing nutritional counseling, adherence to prescribed nutritional programs greatly varies (13-76\%) according to how complex and deep is the involvement of the patient with inadequate eating habits [93]. A recent study investigated the role of SFA on feeding behavior, and epidemiological and experimental data suggest that the indiscriminate consumption of SFA and simple sugars promotes damage in hippocampal regions involved in negative control of appetite and cognitive processing of reward [94].

Finally, glucolipotoxicity describes the synergistic effect of glucose and SFA on the induction of apoptosis in human $\beta$ pancreatic cells, and the presence of an omega- 6 polyunsaturated (LA) or monounsaturated (i.e., oleic acid) fatty acid reduces this toxicity [95]. Several authors have demonstrated the deleterious effect of glucolipotoxicity on pancreatic $\beta$ cells, highlighting its role in the progression of type II diabetes, mitochondrial dysfunction, production of ROS, and deposition of cholesterol and ceramide in $\beta$ cells [96-98]. Novel therapeutic targets for the treatment of type II diabetes now consider the strong synergistic effect of SFA and glucose in progression of the disease $[99,100]$.

Together, these data demonstrate the important neuroprotective role of PUFAs, attenuating the deleterious effects of excessive omega- 6 and SFA consumption in obesity induced by Western diets, and demonstrating the negative impacts of glucolipotoxicity. Intake of the correct amount of fatty acids and carbohydrates plays an essential role in the aging process, neuroinflammation, AD, and other neurodegenerative diseases [101].

\section{Antioxidants}

Central degenerative processes are importantly linked to the excessive production of ROS, which promotes oxidative damage to proteins, lipids, and nucleotides, causing connective and vascular disorders, loss of neuronal content, activation of microglia/macrophages, and induction of mechanisms preceding the onset of $\mathrm{AD}$. The use of antioxidants, such as ascorbic acid (AAC) and vitamin $\mathrm{E}(\mathrm{VE})$, has been shown to be effective in combating the symptoms of cognitive loss and oxidative stress [102].

Humans and primates have lost the ability to synthesize AAC due to absence of the gene coding for L-gulono- $\gamma$-lactone oxidase enzyme (i.e., Gulo), which converts L-gulonolactone into L-ascorbic acid. In animals expressing this enzyme, inactivation of the Gulo gene implies the need for antioxidant supplementation even prenatally, becoming required for survival. If supplementation of AAC is removed, the subjects become anemic, lose weight, and die, presenting damage to vascular integrity, proliferation of smooth muscle cells, and increased oxidative stress, which recruits compensatory antioxidant mechanisms [103,104]. In humans, consumption of approximately $10 \mathrm{mg} /$ day of AAC is enough to prevent the onset of deficiency symptoms [105].

AAC transport into the brain is mediated by the sodium-vitamin C co-transporters 2 (SVCT2), ensuring a sharp concentration gradient through the choroid plexus [106]. Although not responsible for the central concentrations of AAC, SVCT1 transporters are essential for the maintenance of plasma levels of the antioxidant, which in turn modulates the availability of AAC into the cerebrospinal fluid (CSF) and ultimately to the brain.

After cerebrovascular disorders, such as transient ischemia and stroke, AAC absorption and SVCT2 expression rises significantly, especially in capillary endothelial cells located in the ischemic region, indicating that AAC is involved in neutralization of ROS produced by the oxidative stress or 
specifically due to macrophage activity in the damaged region [107]. Lin et al. (2010) showed that intraperitoneal injections of AAC ( $500 \mathrm{mg} / \mathrm{kg}$ in phosphate buffered saline), following compression of the somatosensory cortex of rats, prevented disruption of the $\mathrm{BBB}$ and maintained the integrity of the sensory system [108]. This preservation phenomenon may be extended to other types of BBB damage or cerebrovascular disorders that occur during aging process [109].

Recently, it has been proposed that AAC is involved in prevention of cognitive decay and depression in in vivo models, primarily in situations where damage is promoted by oxidative stress or pro-oxidant agents [110,111]. In a cohort study with 117 elderly individuals, the supplementation of AAC was associated with a lower incidence of severe cognitive impairment, with no effect on verbal ability [112]. Guidi and colleagues (2006) evaluated plasma levels of homocysteine (tHcy), a marker of ROS and total antioxidant capacity, in AD elderly patients with either mild cognitive impairment or vascular dementia. Data obtained showed high levels of tHcy and reduced total antioxidant capacity in $\mathrm{AD}$ and mild cognitive impairment patients. tHcy levels were also high in vascular dementia patients, while lower total antioxidant capacity was exclusively related to AD individuals. ROS levels were homogenous between groups, indicating that the loss of total antioxidant capacity may be related to progression of cognitive complications [113].

Besides the isolated supplementation of AAC, population studies seek to highlight the participation of other dietary components in preventing cognitive/motor impairment and AD progression. In a study from Morris and colleagues, consumption of antioxidant nutrients, VE, $\mathrm{AAC}$, and $\beta$-carotene was investigated in relation to the incidence of $\mathrm{AD}$ in a population of individuals aged over 65 years. In this study, only dietary intake of VE was associated with reduced risk of AD; surprisingly, this relationship was observed only in subjects without the allele ApoE4 [114]. Determining the contribution of a specific antioxidant is, however, a difficult task, as these and other phytochemicals apparently act synergistically when present in foods and complex phytoextracts [115].

Another antioxidant intrinsically involved in the metabolic signs of aging and in pathological dynamics of neurodegenerative diseases is glutathione (GSH), a tripeptide composed of glutamic acid, cysteine, and glycine residues. GSH is the most prevalent thiol compound in cells from virtually all body tissues. GSH is essential for cell proliferation, participates in apoptotic processes and ROS neutralization, and also maintains the reduced form of intracellular protein's sulfhydryl groups [116]. In the brain, GSH is found in higher concentrations in the glial cells, while in neurons the concentrations are slightly lower [117].

GSH is involved in the prevention of mitochondrial damage, cell death, and in the pathogenesis of CNS, providing evidence for the relationship between GSH and diseases such as PD and AD [118,119]. Elucidating the complexity of the neuroprotective mechanisms performed by GSH, in a recent study, it was shown that even non-toxic decreases in GSH concentrations are able to cause an imbalance in $\mathrm{NO}$ activity, allowing nitration of proteins, a predictive marker for neurodegenerative diseases [120].

Attenuation of central levels of GSH, especially in the mitochondria, appears to be a strong indicator of oxidative damage during aging [121]. In a recent work with proton magnetic resonance spectroscopy, authors showed depletion of GSH, increase in lactate, and unchanged levels of AAC in the occipital cortex of elderly compared to young individuals [122]. In another study, Mandal and colleagues showed a linear reduction of GSH concentrations in the frontal cortex during aging, mild cognitive impairment, and diagnosed AD, with gender-specific components [123]. Lower GSH levels were also observed (post-mortem samples) in patients with autism, bipolar disorder, major depression, and schizophrenia $[124,125]$. Finally, recent investigations from our group suggest that GSH may also act as a signaling molecule in CNS (Figure 1), regulating purinergic activity, ion channel opening, and GABA release. Incubation with milimolar concentrations of GSH induces an acute increase in intracellular calcium levels $\left(\left[\mathrm{Ca}^{2+}\right]_{\mathrm{i}}\right)$ and may act in accordance with reducing properties of $\mathrm{GSH}$ during disease and tissue injury [126,127]. 


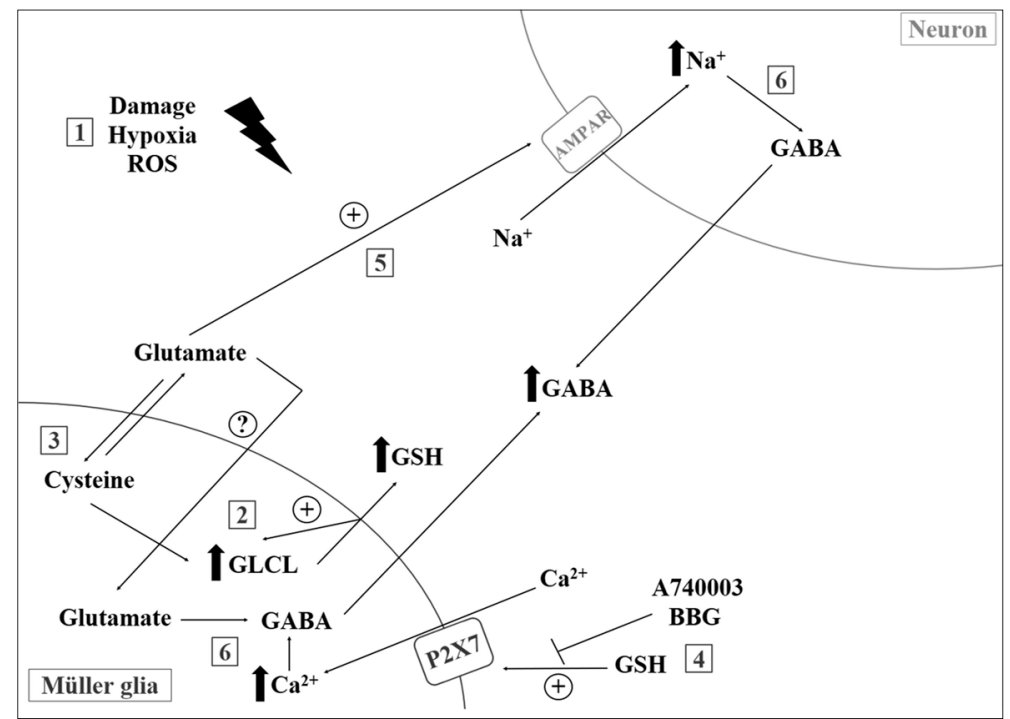

Figure 1. Mechanisms of functional compartmentalization mediated by glutathione in the retinal environment. Tissue damage, hypoxia, and reactive oxygen species (ROS) (1) promote increased activity of antioxidant system intermediates in Müller glial cells, such as $\gamma$-glutamylcysteine ligase (GLCL), which stimulates the synthesis/release of glutathione (GSH) (2) and the uptake of cysteine through a glutamate-cysteine antiporter system (3) When released, GSH is capable of activating P2X7 receptors, allowing for intense $\mathrm{Ca}^{2+}$ increase in the Müller cells (4) while extracellular glutamate promotes activation of AMPA receptors ( $\alpha$-amino-3-hydroxy-5-methyl-4-isoxazolepropionic acid receptors, or AMPAR) in retinal neurons, leading to higher $\mathrm{Na}^{+}$levels in these cells (5) Finally, intracellular $\mathrm{Ca}^{2+}$ (glia) and $\mathrm{Na}^{+}$(neurons) stimulate GABA (gamma-aminobutyric acid) release to the extracellular environment (6). (+) Activation/stimulus. (?) Unknown mechanism.

\section{Physical Activity}

Regular physical activity has several beneficial effects on health, and exercise capacity is a strong and independent predictor of morbidity and mortality for patients of all ages [128,129]. Over the last decades, life expectancy has been increasing, and the continuous reduction in mortality rates among the elderly population is associated with dietary factors and exercise [130]. In fact, exercise not only can improve life expectancy but can also slow down, delay, or prevent many age-associated chronic pathologies, extending healthspan for an optimal longevity [131,132]. Physical activity can also reverse or attenuate the progression of brain aging, being associated with positive vascular, structural, and neuromolecular changes, including insulin resistance, inflammation, and oxidative stress, which contribute to cognitive decline and brain-related diseases [133,134].

\subsection{Physical Activity and Disorders of Cerebral Blood Flow}

The cerebral blood flow is tightly coupled to the cerebral metabolic rate and neuronal metabolism; thus, systemic vascular dysfunction associated with brain hypoperfusion can compromise cognitive performance $[135,136]$. Injuries in endothelium and central/peripheral vascular structure involve increased inflammation and oxidative stress [133]. In addition, cerebral blood flow declines with age $[137,138]$, which strongly contributes to the decrease in cognitive function in the elderly [139]. Exercise, in contrast, increases cerebral blood flow in an intensity-dependent manner and has been shown to improve cognitive function and brain aging $[137,140]$. Aged mice presented lower cerebral blood flow, accompanied by a lower content of endothelial nitric oxide synthase (e-NOS) and vascular endothelial growth factor (VEGF) in the brain microvasculature, when compared to young mice; training in aged mice improved these functional parameters [141]. Mice submitted to running exercise exhibit reduced cerebral lesion sizes after a cerebral ischemia episode, and this effect was blunted in 
the e-NOS deficient mice. Running also improved functional outcome associated with higher cerebral blood flow and angiogenesis in the ischemic striatum, which was completely abrogated in animals treated with L-NAME ( $N$ omega-nitro-L-arginine methyl ester), a NOS inhibitor. These data indicate that exercise improves long-term stroke outcome via NO-dependent mechanisms [142].

In an animal model of vascular dementia induced by bilateral carotid artery occlusion, treadmill exercise reduced the memory impairment caused by the chronic cerebral hypoperfusion and induced hippocampal neurogenesis via the BDNF-pCREB pathway [143]. Imaging analyses conducted both in mice and in young/middle-aged humans showed that exercise-induced neurogenesis associated with increased cerebral blood volume occurs selectively at the hippocampal dentate gyrus [144,145]. Similarly, a study conducted in healthy older humans (60-77 years) also observed that aerobic fitness improvement was associated with positive changes in hippocampal perfusion and early recall and recognition memory; however, these benefits decrease with progressing age, indicating that the capacity for vascular hippocampal plasticity may be age-dependent [146].

\subsection{Brain Volume and the Effect of Physical Activity on Brain Atrophy}

Aging-related brain atrophy is commonly associated with cognitive impairment and memory loss. In fact, the rate, extent, and brain regions showing atrophy can vary among individuals [145]. A recent study by Hanning and colleagues [147] found that brain atrophy in the elderly is associated with higher IL-6 and IL-8 circulating levels, suggesting a role for systemic inflammation in the brain atrophy pathogenesis. Greater brain volumes are associated with greater cognitive reserve and a higher capacity to deal with AD pathology without the clinical manifestation of cognitive impairment [140]. In individuals at the age of 75 years, a higher level of physical activity was associated with better memory performance and with greater volumes of both total brain and white matter $[148,149]$. In addition, higher aerobic fitness level was related to higher hippocampal volume and better memory performance in older non-demented individuals [149], older individuals in the earliest stages of AD [150], and in preadolescent children [151], highlighting the impact of physical activity in increasing brain volume of individuals from all ages. Interestingly, a 42-year follow-up study identified that men with high cardiovascular fitness at age 18 had a lower risk of early-onset dementia and mild cognitive impairment later in life [152].

\subsection{Sexual Dimorphism and Physical Activity}

Sexual dimorphism is observed in brain anatomical structures, neurochemicals, and functions, and not surprisingly men and women also differ in the incidence and nature of CNS-related diseases, such as cognitive impairment, AD, autism, schizophrenia, and eating disorders [153]. In addition, females exhibit stronger immune response, improved antioxidant capacity, better redox, and functional state of their immune cells and, accordingly, the "inflammaging" process in the elderly shows gender differences, including higher serum levels of IL-6 in men than in women $[154,155]$. Elderly individuals with mild cognitive impairment have higher mortality rates, compared with cognitively normal age-matched individuals, and the mortality rate was highest in men [156]. Although cerebral blood flow decreases with age, women have higher levels than men in all ages [157]. The human male brain exhibits more global gene expression changes than the female brain throughout aging, with gene expression mostly down-regulated to 60 years old in men. On the other hand, among older ages, women showed progressively more gene expression changes than men. Interestingly, the major category of down-regulated genes in men was related to protein processing and energy generation [158].

Not surprisingly, exercise impact between genders is also different, and is explored in mixed gender studies. Overall, studies comparing male and female indicate that the positive effect of physical activity or exercise on brain volume, cognition, and AD risk is more pronounced in females [159,160]. However, this subject remains controversial. It was observed that cardiorespiratory fitness was positively associated with total and cortical gray matter volumes in elderly men at increased risk for 
AD [161]. This profile was not observed in women, and authors suggested that cardiorespiratory fitness might be beneficial to brain health, only in men, at the age of 60 years and older.

\subsection{Physical Activity and Brain Disorders of Metabolic Origin}

Insulin is also an important player in the control of degenerative scenarios. In addition to the modulation of energy metabolism, it regulates several features that are essential for healthy aging: cerebral blood flow, inflammatory responses, oxidative stress, A $\beta$ (amyloid beta oligomers) clearance, tau phosphorylation, apoptosis, synaptic plasticity, and memory formation [162]. In humans, insulin resistance and type 2 diabetes have been shown to predict the development of aging-related diseases and a preserved insulin action is strongly associated with longevity [163,164]. AD development and symptoms are closely related to an insulin-resistant brain state, and type 2 diabetes mellitus is a risk factor for dementia and AD [165]. Intranasal insulin therapy in patients with AD or mild cognitive impairment has been associated with improvement in cognitive function [166-168], increased brain volume, including hippocampus, and reduction in the tau-P181/A $\beta 42$ ratio [167].

Exercise can stimulate cellular insulin signaling and sensitivity in peripheral organs [169] and in the brain, with a beneficial impact on brain structure [170] and function [171,172]. A major factor for the development of insulin resistance is obesity [173], and the impact of obesity on unhealthy brain aging has been discussed previously in this review. Exercise is an effective intervention to prevent or treat obesity and obesity-related insulin resistance [174] and improve adipokine profile in obese individuals through the increase of adiponectin and the reduction of hyperleptinemia [175-177]. In addition, the exercise-induced hippocampal neurogenesis was remarkably attenuated in adiponectin-deficient mice, highlighting that adiponectin may be an essential factor mediating this effect via its receptor 1 (adiponectin receptor 1, or ADNR1) and AMPK (5' AMP-activated protein kinase) activation [178].

\subsection{Inflammation and a Role for Physical Activity}

Exercise induces insulin sensitivity and glucose disposal through several pathways, including improvements in inflammation and oxidative stress that are high-risk factors for cognitive impairment and accelerated aging $[163,165]$. In elderly individuals of both sexes, exercise improves inflammatory profile by reducing serum markers, such as C-reactive protein, IL-6, and TNF- $\alpha$ [177,179-182]. In peripheral blood mononuclear cells obtained from aged individuals, exercise training induced lower protein expression of toll-like receptors (TLR2 and TLR4) associated with an anti-inflammatory status linked to myeloid differentiation primary response gene 88 (MyD88)-dependent and MyD88-independent pathways [182]. Additionally, the exercise-induced improvement in inflammatory profile in the elderly was associated with positive changes in cognition [183] and greater total brain volume [184]. In young healthy mice, exercise did not promote changes in serum inflammatory profile; however, reductions in IL- 6 and TNF- $\alpha$ were induced in the hippocampus, indicating that it can promote an anti-inflammatory effect in the brain without affecting the peripheral cytokines production [185]. Although exercise promotes several long-term benefits, including in the proinflammatory state, the acute exercise responses are associated with increased serum levels and tissue expression of IL- 6 and TNF- $\alpha[186,187]$. In a mouse model of traumatic brain injury associated with neurodegeneration and chronic neuroinflammation, it was observed that delayed exercise onset ( 5 weeks after trauma) caused improvements in working and retention memory, decreased lesion volume, increased neurogenesis in the hippocampus, and reduced IL-1b gene expression. However, these improvements were not observed when exercise was initiated 1 week after the brain injury. In fact, it exacerbated chronic classical inflammatory responses, highlighting the importance of timing of exercise onset and its relation to cognitive outcomes and neuroinflammation [188].

\subsection{A Role for Physical Activity in Autophagy and Oxi-Inflammaging}

Autophagy is a physiological and catabolic process, vital for the maintenance of cell homeostasis by effectively clearing dysfunctional organelles such as damaged mitochondria and 
malformed proteins. Disrupted autophagy, however, contributes to unhealthy aging and decreased longevity $[189,190]$. Elderly individuals submitted to exercise training exhibit increased expression of autophagy related-genes, including beclin-1, Atg12, Atg16, and the LC3II/I in peripheral blood mononuclear cells compared with sedentary individuals [191,192]. In addition, the expression of NLRP3, Bcl-2, and Bcl-xL was reduced in peripheral blood mononuclear cells of trained elderly individuals, indicating improvement in autophagy, prevention of NLRP3 inflammasome activation, and reduction of apoptosis [191].

Several studies have revealed that physical activity or exercise elicits a combined effect improving the redox state and enhancing inflammatory defenses, combating the "oxi-inflamm-aging" process [132,155]. Healthy-aged female rats submitted to long-term exercise training showed lower ROS content, lower protein carbonyl content, and increased SOD 1 and SOD 2 (superoxide dismutase 1 and 2) protein expression in the hippocampus compared with sedentary age-matched rats, indicating a beneficial effect on the oxidative status [193]. In an aged mice model of AD (3xTg-AD), voluntary exercise reversed lipoperoxidation and oxidized glutathione levels, while improving the antioxidant enzyme CuZn-SOD content in the cerebral cortex. These changes were associated with optimized behavior and cognition, and reduced amyloid/tau pathology, highlighting the neuroprotective effect of exercise through regulation of redox homeostasis [194]. Neuronal mitochondria are especially susceptible to oxidative stress; therefore, the beneficial impact of exercise on redox balance has many positive effects on mitochondrial function [195]. In young and aged rats, exercise induced a reduction in oxidative stress accompanied by increased mitochondrial biogenesis, dynamics and mitophagy in the brain $[193,196]$.

\subsection{Antineurodegenerative Effect of Muscle Metabolites}

Physical activity and exercise directly affect skeletal muscle physiology. Skeletal muscle is a metabolically active tissue that releases myokines, which might be involved in the beneficial effects of exercise $[197,198]$. Important neural factors associated with neurogenesis, angiogenesis, and cognition, such as BDNF and VEGF, are also produced by skeletal muscle and modulated by exercise. Indeed, the significance of these factors released by the skeletal muscle during exercise to the brain physiology is still unclear. In both young and elderly individuals, the skeletal muscle BDNF expression and the serum concentration of BDNF increase after exercise, and they were associated with structural and functional benefits to the brain [198-200]. However, it has been proposed that the brain contributes with $70-80 \%$ of circulating BDNF both at rest and during exercise; therefore, the systemic impact of the BDNF released from the muscle needs further investigation [201].

Finally, irisin is an exercise-induced myokine that is highly expressed in the brain $[197,202]$. Interestingly, the knockdown of the precursor of irisin, FNDC5, in neuronal precursors impaired their development into mature neurons [203]. Since the FNDC5 expression in the brain is upregulated with exercise, the specific tissue contribution to the beneficial effect of exercise on the brain is still to be defined [202].

\section{Conclusions}

Aging is a sensitive process for the maintenance of the metabolic and functional balance of the brain. When compiled, data indicate the complexity of action and the necessity of various dietary/endogenous antioxidants, in addition to the proper balance in the consumption of essential fatty acids (omega-3 and -6) and physical activity, whose synergistic actions allow for the maintenance of physiological conditions, even during severe metabolic stress (Figure 2). Recent investigations aim to elucidate mechanisms for preventing the intrinsic effects of the aging process in afflictions such as ischemic disorders [204] and the functional decay of mitochondria [205]. However, finding pharmacological or dietary resources capable of significantly intervening with the neurodegenerative processes remains a great challenge, and several groups are currently in a collective effort to narrow the therapeutic spectrum into a more realistic set of approaches [206-208]. Future research should 
rely on novel integrative methods present in systems biology, which allows for a broad analysis of the metabolic interactions in aging and disease processes.

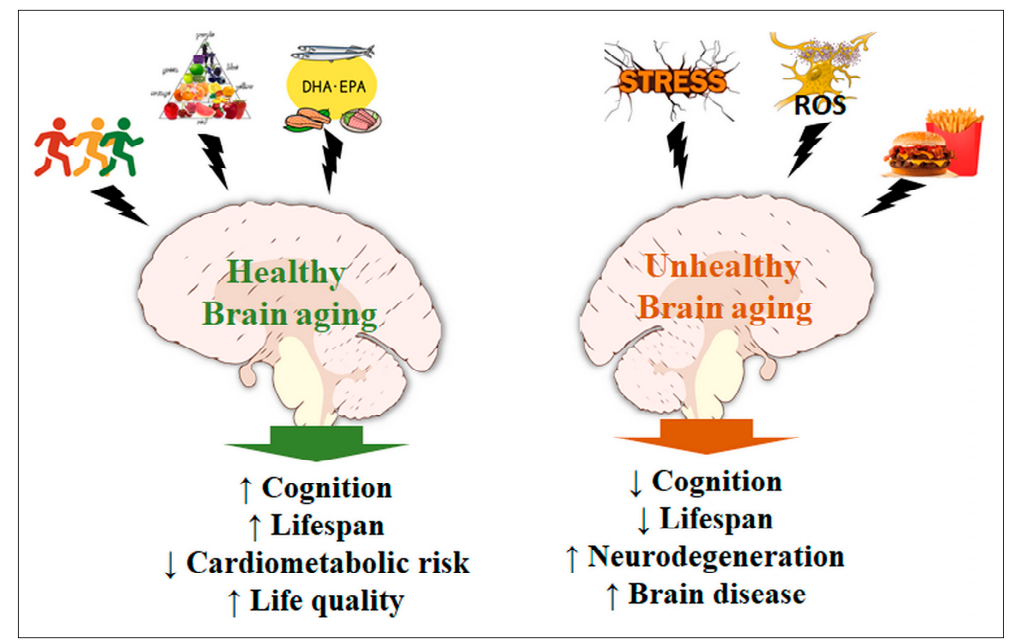

Figure 2. Brain dynamics in healthy and unhealthy aging. Moderate physical activity, low-calorie diets, and essential fatty acids are amongst the main elements of a healthy brain, where we observe less or no cognitive decline, greater lifespan, reduced cardiovascular (and metabolic) risks, and thus overall better quality of life. Conversely, a continuously stressed brain, either by an unstable environment or by chemical mediators (e.g., ROS, reactive nitrogen species and other radicals) will suffer from cognitive decline and increased risk for neurodegeneration and other brain diseases, while affecting the individual's lifespan. Also, high caloric meals and/or typical cafeteria diets are risk factors for the development of several such affections. ( $\uparrow$ Increased. $(\downarrow)$ Decreased.

Acknowledgments: Grants from Fundação de Amparo à Pesquisa do Estado do Rio de Janeiro (FAPERJ), Conselho Nacional de Desenvolvimento Científico e Tecnológico (CNPq), and Instituto Nacional de Ciência e Tecnologia de Neurociênca Translacional (INCT-INNT) supported this work. H.R.F. is recipient of a Ph.D. research fellowship from Conselho Nacional de Desenvolvimento Científico e Tecnológico (CNPq). R.A.d.M.R., I.H.T., K.J.O. and G.d.C.F. receive a research fellowship from CNPq.

Author Contributions: H.R.F., R.A.d.M.R., I.H.T., K.J.O. and G.d.C.F. equally wrote and reviewed the work.

Conflicts of Interest: The authors declare no conflict of interest.

\section{References}

1. Khaw, K.T. Epidemiological aspects of ageing. Philos. Trans. R. Soc. Lond. Ser. B Biol. Sci. 1997, 352, $1829-1835$. [CrossRef] [PubMed]

2. Finch, C.E. Evolution in health and medicine Sackler colloquium: Evolution of the human lifespan and diseases of aging: Roles of infection, inflammation, and nutrition. Proc. Natl. Acad. Sci. USA 2010, 107 (Suppl. 1), 1718-1724. [CrossRef] [PubMed]

3. Frangeskou, M.; Lopez-Valcarcel, B.; Serra-Majem, L. Dehydration in the Elderly: A Review Focused on Economic Burden. J. Nutr. Health Aging 2015, 19, 619-627. [CrossRef] [PubMed]

4. Milan, A.M.; D'Souza, R.F.; Pundir, S.; Pileggi, C.A.; Thorstensen, E.B.; Barnett, M.P.; Markworth, J.F.; Cameron-Smith, D.; Mitchell, C.J. Older adults have delayed amino acid absorption after a high protein mixed breakfast meal. J. Nutr. Health Aging 2015, 19, 839-845. [CrossRef] [PubMed]

5. Nguyen, T.N.; Cumming, R.G.; Hilmer, S.N. A review of frailty in developing countries. J. Nutr. Health Aging 2015, 19, 941-946. [CrossRef] [PubMed]

6. Corona, L.P.; Andrade, F.C.D.; Duarte, Y.A.D.; Lebrao, M.L. The relationship between anemia, hemoglobin concentration and frailty in Brazilian older adults. J. Nutr. Health Aging 2015, 19, 935-940. [CrossRef] [PubMed] 
7. Kearney, J. Food consumption trends and drivers. Philos. Trans. R. Soc. Lond. Ser. B Biol. Sci. 2010, 365, 2793-2807. [CrossRef] [PubMed]

8. Miller, M.S.; Callahan, D.M.; Toth, M.J. Skeletal muscle myofilament adaptations to aging, disease, and disuse and their effects on whole muscle performance in older adult humans. Front. Physiol. 2014, 5, 369. [CrossRef] [PubMed]

9. Newgard, C.B.; Pessin, J.E. Recent progress in metabolic signaling pathways regulating aging and life span. J. Gerontol. Ser. A Biol. Sci. Med. Sci. 2014, 69 (Suppl. 1), S21-S27. [CrossRef] [PubMed]

10. Popkin, B.M. The nutrition transition and obesity in the developing world. J. Nutr. 2001, 131, 871s-873s. [PubMed]

11. Hossain, P.; Kawar, B.; Nahas, M.E. Obesity and diabetes in the developing world-A growing challenge. N. Engl. J. Med. 2007, 356, 213-215. [CrossRef] [PubMed]

12. Steptoe, A.; Deaton, A.; Stone, A.A. Subjective wellbeing, health, and ageing. Lancet 2015, 385, 640-648. [CrossRef]

13. Goodman, E.; Whitaker, R.C. A prospective study of the role of depression in the development and persistence of adolescent obesity. Pediatrics 2002, 110, 497-504. [CrossRef] [PubMed]

14. Onyike, C.U.; Crum, R.M.; Lee, H.B.; Lyketsos, C.G.; Eaton, W.W. Is obesity associated with major depression? Results from the Third National Health and Nutrition Examination Survey. Am. J. Epidemiol. 2003, 158, 1139-1147. [CrossRef] [PubMed]

15. McCarty, C.A.; Kosterman, R.; Mason, W.A.; McCauley, E.; Hawkins, J.D.; Herrenkohl, T.I.; Lengua, L.J. Longitudinal associations among depression, obesity and alcohol use disorders in young adulthood. Gen. Hosp. Psychiatry 2009, 31, 442-450. [CrossRef] [PubMed]

16. Saunier, K.; Dore, J. Gastrointestinal tract and the elderly: Functional foods, gut microflora and healthy ageing. Dig. Liver Dis. 2002, 34 (Suppl. 2), S19-S24. [CrossRef]

17. Lopez-Leon, M.; Outeiro, T.F.; Goya, R.G. Cell reprogramming: Therapeutic potential and the promise of rejuvenation for the aging brain. Ageing Res. Rev. 2017, 40, 168-181. [CrossRef] [PubMed]

18. Cararo, J.H.; Streck, E.L.; Schuck, P.F.; Ferreira Gda, C. Carnosine and related peptides: Therapeutic potential in age-related disorders. Aging Dis. 2015, 6, 369-379. [CrossRef] [PubMed]

19. Jager, K.; Walter, M. Therapeutic targeting of telomerase. Genes 2016, 7, 39. [CrossRef] [PubMed]

20. Wang, Y.; Xu, Q.; Sack, L.; Kang, C.; Elledge, S.J. A gain-of-function senescence bypass screen identifies the homeobox transcription factor DLX2 as a regulator of ATM-p53 signaling. Genes Dev. 2016, 30, $293-306$. [CrossRef] [PubMed]

21. Giordano, S.; Darley-Usmar, V.; Zhang, J. Autophagy as an essential cellular antioxidant pathway in neurodegenerative disease. Redox Biol. 2014, 2, 82-90. [CrossRef] [PubMed]

22. Poon, H.F.; Calabrese, V.; Calvani, M.; Butterfield, D.A. Proteomics analyses of specific protein oxidation and protein expression in aged rat brain and its modulation by L-acetylcarnitine: Insights into the mechanisms of action of this proposed therapeutic agent for CNS disorders associated with oxidative stress. Antioxid. Redox Signal. 2006, 8, 381-394. [CrossRef] [PubMed]

23. Lionaki, E.; Tavernarakis, N. Oxidative stress and mitochondrial protein quality control in aging. J. Proteom. 2013, 92, 181-194. [CrossRef] [PubMed]

24. Kudryavtseva, A.V.; Krasnov, G.S.; Dmitriev, A.A.; Alekseev, B.Y.; Kardymon, O.L.; Sadritdinova, A.F.; Fedorova, M.S.; Pokrovsky, A.V.; Melnikova, N.V.; Kaprin, A.D.; et al. Mitochondrial dysfunction and oxidative stress in aging and cancer. Oncotarget 2016, 7, 44879-44905. [CrossRef] [PubMed]

25. Samson, R.D.; Barnes, C.A. Impact of aging brain circuits on cognition. Eur. J. Neurosci. 2013, 37, $1903-1915$. [CrossRef] [PubMed]

26. Shigenaga, M.K.; Hagen, T.M.; Ames, B.N. Oxidative damage and mitochondrial decay in aging. Proc. Natl. Acad. Sci. USA 1994, 91, 10771-10778. [CrossRef] [PubMed]

27. Xiong, J.; Camello, P.J.; Verkhratsky, A.; Toescu, E.C. Mitochondrial polarisation status and $\left[\mathrm{Ca}^{2+}\right]_{\mathrm{i}}$ signalling in rat cerebellar granule neurones aged in vitro. Neurobiol. Aging 2004, 25, 349-359. [CrossRef]

28. Murchison, D.; Zawieja, D.C.; Griffith, W.H. Reduced mitochondrial buffering of voltage-gated calcium influx in aged rat basal forebrain neurons. Cell Calcium 2004, 36, 61-75. [CrossRef] [PubMed]

29. Tatarkova, Z.; Kovalska, M.; Timkova, V.; Racay, P.; Lehotsky, J.; Kaplan, P. The effect of aging on mitochondrial complex I and the extent of oxidative stress in the rat brain cortex. Neurochem. Res. 2016, 41, 2160-2172. [CrossRef] [PubMed] 
30. Miquel, J. An update on the mitochondrial-DNA mutation hypothesis of cell aging. Mutat. Res. 1992, 275, 209-216. [CrossRef]

31. Bertoni-Freddari, C.; Fattoretti, P.; Casoli, T.; Spagna, C.; Meier-Ruge, W. Morphological alterations of synaptic mitochondria during aging. The effect of Hydergine treatment. Ann. N. Y. Acad. Sci. 1994, 717, 137-149. [CrossRef] [PubMed]

32. Sastre, J.; Millan, A.; Garcia de la Asuncion, J.; Pla, R.; Juan, G.; Pallardo, F.V.; O'Connor, E.; Martin, J.A.; Droy-Lefaix, M.T.; Vina, J. A Ginkgo biloba extract (EGb 761) prevents mitochondrial aging by protecting against oxidative stress. Free Radic. Biol. Med. 1998, 24, 298-304.

33. Wakabayashi, T. Megamitochondria formation-physiology and pathology. J. Cell. Mol. Med. 2002, 6, 497-538. [CrossRef] [PubMed]

34. Nicholls, D.G. Mitochondrial membrane potential and aging. Aging Cell 2004, 3, 35-40. [CrossRef] [PubMed]

35. Sik, A.; Penttonen, M.; Buzsaki, G. Interneurons in the hippocampal dentate gyrus: An in vivo intracellular study. Eur. J. Neurosci. 1997, 9, 573-588. [CrossRef] [PubMed]

36. Kann, O.; Papageorgiou, I.E.; Draguhn, A. Highly energized inhibitory interneurons are a central element for information processing in cortical networks. J. Cereb. Blood Flow Metab. 2014, 34, 1270-1282. [CrossRef] [PubMed]

37. Swerdlow, R.H. Brain aging, Alzheimer's disease, and mitochondria. Biochim. Biophys. Acta 2011, 1812, 1630-1639. [CrossRef] [PubMed]

38. Cunnane, S.; Nugent, S.; Roy, M.; Courchesne-Loyer, A.; Croteau, E.; Tremblay, S.; Castellano, A.; Pifferi, F.; Bocti, C.; Paquet, N.; et al. Brain fuel metabolism, aging, and Alzheimer's disease. Nutrition 2011, 27, 3-20. [CrossRef] [PubMed]

39. Zoncu, R.; Efeyan, A.; Sabatini, D.M. mTOR: From growth signal integration to cancer, diabetes and ageing. Nat. Rev. Mol. Cell Biol. 2011, 12, 21-35. [CrossRef] [PubMed]

40. Cornu, M.; Albert, V.; Hall, M.N. mTOR in aging, metabolism, and cancer. Curr. Opin. Genet. Dev. 2013, 23, 53-62. [CrossRef] [PubMed]

41. Perluigi, M.; Di Domenico, F.; Butterfield, D.A. mTOR signaling in aging and neurodegeneration: At the crossroad between metabolism dysfunction and impairment of autophagy. Neurobiol. Dis. 2015, 84, 39-49. [CrossRef] [PubMed]

42. Bitarafan, S.; Harirchian, M.H.; Nafissi, S.; Sahraian, M.A.; Togha, M.; Siassi, F.; Saedisomeolia, A.; Alipour, E.; Mohammadpour, N.; Chamary, M.; et al. Dietary intake of nutrients and its correlation with fatigue in multiple sclerosis patients. Iran. J. Neurol. 2014, 13, 28-32. [PubMed]

43. Mi, W.; van Wijk, N.; Cansev, M.; Sijben, J.W.; Kamphuis, P.J. Nutritional approaches in the risk reduction and management of Alzheimer's disease. Nutrition 2013, 29, 1080-1089. [CrossRef] [PubMed]

44. Tomi, M.; Zhao, Y.; Thamotharan, S.; Shin, B.C.; Devaskar, S.U. Early life nutrient restriction impairs blood-brain metabolic profile and neurobehavior predisposing to Alzheimer's disease with aging. Brain Res. 2013, 1495, 61-75. [CrossRef] [PubMed]

45. Banks, W.A.; Abrass, C.K.; Hansen, K.M. Differentiating the influences of aging and adiposity on brain weights, levels of serum and brain cytokines, gastrointestinal hormones, and amyloid precursor protein. J. Gerontol. Ser. A Biol. Sci. Med. Sci. 2016, 71, 21-29. [CrossRef] [PubMed]

46. Purkayastha, S.; Cai, D. Disruption of neurogenesis by hypothalamic inflammation in obesity or aging. Rev. Endocr. Metab. Disord. 2013, 14, 351-356. [CrossRef] [PubMed]

47. Ahima, R.S. Digging deeper into obesity. J. Clin. Investig. 2011, 121, 2076-2079. [CrossRef] [PubMed]

48. Tucsek, Z.; Toth, P.; Sosnowska, D.; Gautam, T.; Mitschelen, M.; Koller, A.; Szalai, G.; Sonntag, W.E.; Ungvari, Z.; Csiszar, A. Obesity in aging exacerbates blood-brain barrier disruption, neuroinflammation, and oxidative stress in the mouse hippocampus: Effects on expression of genes involved in beta-amyloid generation and Alzheimer's disease. J. Gerontol. Ser. A Biol. Sci. Med. Sci. 2014, 69, 1212-1226. [CrossRef] [PubMed]

49. Youm, Y.H.; Grant, R.W.; McCabe, L.R.; Albarado, D.C.; Nguyen, K.Y.; Ravussin, A.; Pistell, P.; Newman, S.; Carter, R.; Laque, A.; et al. Canonical Nlrp3 inflammasome links systemic low-grade inflammation to functional decline in aging. Cell Metab. 2013, 18, 519-532. [CrossRef] [PubMed]

50. De Souza, C.T.; Araujo, E.P.; Bordin, S.; Ashimine, R.; Zollner, R.L.; Boschero, A.C.; Saad, M.J.; Velloso, L.A. Consumption of a fat-rich diet activates a proinflammatory response and induces insulin resistance in the hypothalamus. Endocrinology 2005, 146, 4192-4199. [CrossRef] [PubMed] 
51. Batsis, J.A.; Mackenzie, T.A.; Vasquez, E.; Germain, C.M.; Emeny, R.T.; Rippberger, P.; Lopez-Jimenez, F.; Bartels, S.J. Association of adiposity, telomere length and mortality: Data from the NHANES 1999-2002. Int. J. Obes. 2017. [CrossRef] [PubMed]

52. Rodriguez, A.; Ezquerro, S.; Mendez-Gimenez, L.; Becerril, S.; Fruhbeck, G. Revisiting the adipocyte: A model for integration of cytokine signaling in the regulation of energy metabolism. Am. J. Physiol. Endocrinol. Metab. 2015, 309, E691-E714. [CrossRef] [PubMed]

53. Strissel, K.J.; DeFuria, J.; Shaul, M.E.; Bennett, G.; Greenberg, A.S.; Obin, M.S. T-cell recruitment and Th1 polarization in adipose tissue during diet-induced obesity in C57BL/6 mice. Obesity 2010, 18, 1918-1925. [CrossRef] [PubMed]

54. Castoldi, A.; Naffah de Souza, C.; Camara, N.O.; Moraes-Vieira, P.M. The Macrophage Switch in Obesity Development. Front. Immunol. 2015, 6, 637. [CrossRef] [PubMed]

55. Friedman, J.M.; Halaas, J.L. Leptin and the regulation of body weight in mammals. Nature 1998, 395, 763-770. [CrossRef] [PubMed]

56. Sahu, A. Leptin decreases food intake induced by melanin-concentrating hormone (MCH), galanin (GAL) and neuropeptide Y (NPY) in the rat. Endocrinology 1998, 139, 4739-4742. [CrossRef] [PubMed]

57. Ahima, R.S.; Osei, S.Y. Leptin signaling. Physiol. Behav. 2004, 81, 223-241. [CrossRef] [PubMed]

58. Bjorbaek, C.; Elmquist, J.K.; Frantz, J.D.; Shoelson, S.E.; Flier, J.S. Identification of SOCS-3 as a potential mediator of central leptin resistance. Mol. Cell 1998, 1, 619-625. [CrossRef]

59. Zhang, G.; Li, J.; Purkayastha, S.; Tang, Y.; Zhang, H.; Yin, Y.; Li, B.; Liu, G.; Cai, D. Hypothalamic programming of systemic ageing involving IKK-beta, NF-kappaB and GnRH. Nature 2013, 497, 211-216. [CrossRef] [PubMed]

60. Horrillo, D.; Sierra, J.; Arribas, C.; Garcia-San Frutos, M.; Carrascosa, J.M.; Lauzurica, N.; Fernandez-Agullo, T.; Ros, M. Age-associated development of inflammation in Wistar rats: Effects of caloric restriction. Arch. Physiol. Biochem. 2011, 117, 140-150. [CrossRef] [PubMed]

61. Koenig, S.; Luheshi, G.N.; Wenz, T.; Gerstberger, R.; Roth, J.; Rummel, C. Leptin is involved in age-dependent changes in response to systemic inflammation in the rat. Brain Behav. Immun. 2014, 36, 128-138. [CrossRef] [PubMed]

62. McGuire, M.J.; Ishii, M. Leptin Dysfunction and Alzheimer's Disease: Evidence from Cellular, Animal, and Human Studies. Cell. Mol. Neurobiol. 2016, 36, 203-217. [CrossRef] [PubMed]

63. Ronan, L.; Alexander-Bloch, A.F.; Wagstyl, K.; Farooqi, S.; Brayne, C.; Tyler, L.K.; Fletcher, P.C. Obesity associated with increased brain age from midlife. Neurobiol. Aging 2016, 47, 63-70. [CrossRef] [PubMed]

64. Narita, K.; Kosaka, H.; Okazawa, H.; Murata, T.; Wada, Y. Relationship between plasma leptin level and brain structure in elderly: A voxel-based morphometric study. Biol. Psychiatry 2009, 65, 992-994. [CrossRef] [PubMed]

65. Holden, K.F.; Lindquist, K.; Tylavsky, F.A.; Rosano, C.; Harris, T.B.; Yaffe, K. Serum leptin level and cognition in the elderly: Findings from the Health ABC Study. Neurobiol. Aging 2009, 30, 1483-1489. [CrossRef] [PubMed]

66. Lieb, W.; Beiser, A.S.; Vasan, R.S.; Tan, Z.S.; Au, R.; Harris, T.B.; Roubenoff, R.; Auerbach, S.; DeCarli, C.; Wolf, P.A.; et al. Association of plasma leptin levels with incident Alzheimer disease and MRI measures of brain aging. J. Am. Med. Assoc. 2009, 302, 2565-2572. [CrossRef] [PubMed]

67. Gorska-Ciebiada, M.; Saryusz-Wolska, M.; Borkowska, A.; Ciebiada, M.; Loba, J. Adiponectin, leptin and IL-1 beta in elderly diabetic patients with mild cognitive impairment. Metab. Brain Dis. 2016, 31, 257-266. [CrossRef] [PubMed]

68. Rajagopalan, P.; Toga, A.W.; Jack, C.R.; Weiner, M.W.; Thompson, P.M. Fat-mass-related hormone, plasma leptin, predicts brain volumes in the elderly. Neuroreport 2013, 24, 58-62. [CrossRef] [PubMed]

69. Mattson, M.P. Lifelong brain health is a lifelong challenge: From evolutionary principles to empirical evidence. Ageing Res. Rev. 2015, 20, 37-45. [CrossRef] [PubMed]

70. Phillips, C. Lifestyle modulators of neuroplasticity: How physical activity, mental engagement, and diet promote cognitive health during aging. Neural Plast. 2017, 2017, 3589271. [CrossRef] [PubMed]

71. Jesko, H.; Wencel, P.; Strosznajder, R.P.; Strosznajder, J.B. Sirtuins and their roles in brain aging and neurodegenerative disorders. Neurochem. Res. 2017, 42, 876-890. [CrossRef] [PubMed] 
72. Cohen, D.E.; Supinski, A.M.; Bonkowski, M.S.; Donmez, G.; Guarente, L.P. Neuronal SIRT1 regulates endocrine and behavioral responses to calorie restriction. Genes Dev. 2009, 23, 2812-2817. [CrossRef] [PubMed]

73. Fusco, S.; Ripoli, C.; Podda, M.V.; Ranieri, S.C.; Leone, L.; Toietta, G.; McBurney, M.W.; Schutz, G.; Riccio, A.; Grassi, C.; et al. A role for neuronal cAMP responsive-element binding (CREB)-1 in brain responses to calorie restriction. Proc. Natl. Acad. Sci. USA 2012, 109, 621-626. [CrossRef] [PubMed]

74. Li, D.; Liu, N.; Zhao, H.H.; Zhang, X.; Kawano, H.; Liu, L.; Zhao, L.; Li, H.P. Interactions between Sirt1 and MAPKs regulate astrocyte activation induced by brain injury in vitro and in vivo. J. Neuroinflamm. 2017, 14, 67. [CrossRef] [PubMed]

75. Moussa, C.; Hebron, M.; Huang, X.; Ahn, J.; Rissman, R.A.; Aisen, P.S.; Turner, R.S. Resveratrol regulates neuro-inflammation and induces adaptive immunity in Alzheimer's disease. J. Neuroinflamm. 2017, 14, 1. [CrossRef] [PubMed]

76. Freitas, H.R.; Isaac, A.R.; Malcher-Lopes, R.; Diaz, B.L.; Trevenzoli, I.H.; De Melo Reis, R.A. Polyunsaturated fatty acids and endocannabinoids in health and disease. Nutr. Neurosci. 2017, 1-20. [CrossRef] [PubMed]

77. Simopoulos, A.P. Essential fatty acids in health and chronic disease. Am. J. Clin. Nutr. 1999, 70, 560s-569s. [PubMed]

78. Simopoulos, A.P. The importance of the ratio of omega-6/omega-3 essential fatty acids. Biomed. Pharm. 2002, 56, 365-379. [CrossRef]

79. Denis, I.; Potier, B.; Vancassel, S.; Heberden, C.; Lavialle, M. Omega-3 fatty acids and brain resistance to ageing and stress: Body of evidence and possible mechanisms. Ageing Res. Rev. 2013, 12, 579-594. [CrossRef] [PubMed]

80. Denis, I.; Potier, B.; Heberden, C.; Vancassel, S. Omega-3 polyunsaturated fatty acids and brain aging. Curr. Opin. Clin. Nutr. Metab. Care 2015, 18, 139-146. [CrossRef] [PubMed]

81. Haast, R.A.; Kiliaan, A.J. Impact of fatty acids on brain circulation, structure and function. Prostaglandins Leukot. Essent. Fat. Acids 2015, 92, 3-14. [CrossRef] [PubMed]

82. Latour, A.; Grintal, B.; Champeil-Potokar, G.; Hennebelle, M.; Lavialle, M.; Dutar, P.; Potier, B.; Billard, J.M.; Vancassel, S.; Denis, I. Omega-3 fatty acids deficiency aggravates glutamatergic synapse and astroglial aging in the rat hippocampal CA1. Aging Cell 2013, 12, 76-84. [CrossRef] [PubMed]

83. Chouinard-Watkins, R.; Plourde, M. Fatty acid metabolism in carriers of apolipoprotein E epsilon 4 allele: Is it contributing to higher risk of cognitive decline and coronary heart disease? Nutrients 2014, 6, 4452-4471. [CrossRef] [PubMed]

84. Salem, N., Jr.; Vandal, M.; Calon, F. The benefit of docosahexaenoic acid for the adult brain in aging and dementia. Prostaglandins Leukot. Essent. Fat. Acids 2015, 92, 15-22. [CrossRef] [PubMed]

85. Nagasawa, M.; Hara, T.; Kashino, A.; Akasaka, Y.; Ide, T.; Murakami, K. Identification of a functional peroxisome proliferator-activated receptor (PPAR) response element (PPRE) in the human apolipoprotein A-IV gene. Biochem. Pharmacol. 2009, 78, 523-530. [CrossRef] [PubMed]

86. Xue, B.; Yang, Z.; Wang, X.; Shi, H. Omega-3 polyunsaturated fatty acids antagonize macrophage inflammation via activation of AMPK/SIRT1 pathway. PLoS ONE 2012, 7, e45990. [CrossRef] [PubMed]

87. Bernardo, A.; Minghetti, L. PPAR-gamma agonists as regulators of microglial activation and brain inflammation. Curr. Pharm. Des. 2006, 12, 93-109. [CrossRef] [PubMed]

88. Heneka, M.T.; Landreth, G.E. PPARs in the brain. Biochim. Biophys. Acta 2007, 1771, 1031-1045. [CrossRef] [PubMed]

89. Culman, J.; Zhao, Y.; Gohlke, P.; Herdegen, T. PPAR-gamma: Therapeutic target for ischemic stroke. Trends Pharmacol. Sci. 2007, 28, 244-249. [CrossRef] [PubMed]

90. Afshordel, S.; Hagl, S.; Werner, D.; Rohner, N.; Kogel, D.; Bazan, N.G.; Eckert, G.P. Omega-3 polyunsaturated fatty acids improve mitochondrial dysfunction in brain aging-Impact of Bcl-2 and NPD-1 like metabolites. Prostaglandins Leukot. Essent. Fat. Acids 2015, 92, 23-31. [CrossRef] [PubMed]

91. Cutuli, D.; De Bartolo, P.; Caporali, P.; Laricchiuta, D.; Foti, F.; Ronci, M.; Rossi, C.; Neri, C.; Spalletta, G.; Caltagirone, C.; et al. n-3 polyunsaturated fatty acids supplementation enhances hippocampal functionality in aged mice. Front. Aging Neurosci. 2014, 6, 220. [CrossRef] [PubMed]

92. Kaplan, R.J.; Greenwood, C.E. Dietary saturated fatty acids and brain function. Neurochem. Res. 1998, 23, 615-626. [CrossRef] [PubMed] 
93. Burke, L.E.; Dunbar-Jacob, J. Adherence to medication, diet, and activity recommendations: From assessment to maintenance. J. Cardiovasc. Nurs. 1995, 9, 62-79. [CrossRef] [PubMed]

94. Kanoski, S.E.; Davidson, T.L. Western diet consumption and cognitive impairment: Links to hippocampal dysfunction and obesity. Physiol. Behav. 2011, 103, 59-68. [CrossRef] [PubMed]

95. El-Assaad, W.; Buteau, J.; Peyot, M.L.; Nolan, C.; Roduit, R.; Hardy, S.; Joly, E.; Dbaibo, G.; Rosenberg, L.; Prentki, M. Saturated fatty acids synergize with elevated glucose to cause pancreatic beta-cell death. Endocrinology 2003, 144, 4154-4163. [CrossRef] [PubMed]

96. El-Assaad, W.; Joly, E.; Barbeau, A.; Sladek, R.; Buteau, J.; Maestre, I.; Pepin, E.; Zhao, S.; Iglesias, J.; Roche, E.; et al. Glucolipotoxicity alters lipid partitioning and causes mitochondrial dysfunction, cholesterol, and ceramide deposition and reactive oxygen species production in INS832/13 ss-cells. Endocrinology 2010, 151, 3061-3073. [CrossRef] [PubMed]

97. Fontes, G.; Zarrouki, B.; Hagman, D.K.; Latour, M.G.; Semache, M.; Roskens, V.; Moore, P.C.; Prentki, M.; Rhodes, C.J.; Jetton, T.L.; et al. Glucolipotoxicity age-dependently impairs beta cell function in rats despite a marked increase in beta cell mass. Diabetologia 2010, 53, 2369-2379. [CrossRef] [PubMed]

98. Poitout, V.; Amyot, J.; Semache, M.; Zarrouki, B.; Hagman, D.; Fontes, G. Glucolipotoxicity of the pancreatic beta cell. Biochim. Biophys. Acta 2010, 1801, 289-298. [CrossRef] [PubMed]

99. Van Raalte, D.H.; Diamant, M. Glucolipotoxicity and beta cells in type 2 diabetes mellitus: Target for durable therapy? Diabetes Res. Clin. Pract. 2011, 93 (Suppl. 1), S37-S46. [CrossRef]

100. Liu, Z.; Stanojevic, V.; Brindamour, L.J.; Habener, J.F. GLP1-derived nonapeptide GLP1(28-36)amide protects pancreatic beta-cells from glucolipotoxicity. J. Endocrinol. 2012, 213, 143-154. [CrossRef] [PubMed]

101. Bazan, N.G.; Molina, M.F.; Gordon, W.C. Docosahexaenoic acid signalolipidomics in nutrition: Significance in aging, neuroinflammation, macular degeneration, Alzheimer's, and other neurodegenerative diseases. Ann. Rev. Nutr. 2011, 31, 321-351. [CrossRef] [PubMed]

102. Head, E.; Rofina, J.; Zicker, S. Oxidative stress, aging, and central nervous system disease in the canine model of human brain aging. Vet. Clin. N. Am. Small Anim. Pract. 2008, 38, 167-178. [CrossRef] [PubMed]

103. Maeda, N.; Hagihara, H.; Nakata, Y.; Hiller, S.; Wilder, J.; Reddick, R. Aortic wall damage in mice unable to synthesize ascorbic acid. Proc. Natl. Acad. Sci. USA 2000, 97, 841-846. [CrossRef] [PubMed]

104. Harrison, F.E.; Meredith, M.E.; Dawes, S.M.; Saskowski, J.L.; May, J.M. Low ascorbic acid and increased oxidative stress in gulo(-/-) mice during development. Brain Res. 2010, 1349, 143-152. [CrossRef] [PubMed]

105. Hodges, R.E.; Hood, J.; Canham, J.E.; Sauberlich, H.E.; Baker, E.M. Clinical manifestations of ascorbic acid deficiency in man. Am. J. Clin. Nutr. 1971, 24, 432-443. [PubMed]

106. Harrison, F.E.; May, J.M. Vitamin C function in the brain: Vital role of the ascorbate transporter SVCT2. Free Radic. Biol. Med. 2009, 46, 719-730. [CrossRef] [PubMed]

107. Gess, B.; Sevimli, S.; Strecker, J.K.; Young, P.; Schabitz, W.R. Sodium-dependent vitamin C transporter 2 (SVCT2) expression and activity in brain capillary endothelial cells after transient ischemia in mice. PLoS ONE 2011, 6, e17139. [CrossRef] [PubMed]

108. Lin, J.L.; Huang, Y.H.; Shen, Y.C.; Huang, H.C.; Liu, P.H. Ascorbic acid prevents blood-brain barrier disruption and sensory deficit caused by sustained compression of primary somatosensory cortex. J. Cereb. Blood Flow Metab. 2010, 30, 1121-1136. [CrossRef] [PubMed]

109. Hall, E.D.; Vaishnav, R.A.; Mustafa, A.G. Antioxidant therapies for traumatic brain injury. Neurotherapeutics 2010, 7, 51-61. [CrossRef] [PubMed]

110. Narayanan, S.N.; Kumar, R.S.; Paval, J.; Nayak, S. Effect of ascorbic acid on the monosodium glutamate-induced neurobehavioral changes in periadolescent rats. Bratisl. Lek. Listy 2010, 111, 247-252. [PubMed]

111. Moretti, M.; Colla, A.; de Oliveira Balen, G.; dos Santos, D.B.; Budni, J.; de Freitas, A.E.; Farina, M.; Severo Rodrigues, A.L. Ascorbic acid treatment, similarly to fluoxetine, reverses depressive-like behavior and brain oxidative damage induced by chronic unpredictable stress. J. Psychiatr. Res. 2012, 46, 331-340. [CrossRef] [PubMed]

112. Paleologos, M.; Cumming, R.G.; Lazarus, R. Cohort study of vitamin C intake and cognitive impairment. Am. J. Epidemiol. 1998, 148, 45-50. [CrossRef] [PubMed]

113. Guidi, I.; Galimberti, D.; Lonati, S.; Novembrino, C.; Bamonti, F.; Tiriticco, M.; Fenoglio, C.; Venturelli, E.; Baron, P.; Bresolin, N.; et al. Oxidative imbalance in patients with mild cognitive impairment and Alzheimer's disease. Neurobiol. Aging 2006, 27, 262-269. [CrossRef] [PubMed] 
114. Morris, M.C.; Evans, D.A.; Bienias, J.L.; Tangney, C.C.; Bennett, D.A.; Aggarwal, N.; Wilson, R.S.; Scherr, P.A. Dietary intake of antioxidant nutrients and the risk of incident Alzheimer disease in a biracial community study. J. Am. Med. Assoc. 2002, 287, 3230-3237. [CrossRef]

115. Joseph, J.A.; Shukitt-Hale, B.; Denisova, N.A.; Bielinski, D.; Martin, A.; McEwen, J.J.; Bickford, P.C. Reversals of age-related declines in neuronal signal transduction, cognitive, and motor behavioral deficits with blueberry, spinach, or strawberry dietary supplementation. J. Neurosci. 1999, 19, 8114-8121. [PubMed]

116. Dringen, R. Metabolism and functions of glutathione in brain. Prog. Neurobiol. 2000, 62, 649-671. [CrossRef]

117. Rice, M.E.; Russo-Menna, I. Differential compartmentalization of brain ascorbate and glutathione between neurons and glia. Neuroscience 1998, 82, 1213-1223. [CrossRef]

118. Kish, S.J.; Morito, C.; Hornykiewicz, O. Glutathione peroxidase activity in Parkinson's disease brain. Neurosci. Lett. 1985, 58, 343-346. [CrossRef]

119. Volicer, L.; Crino, P.B. Involvement of free radicals in dementia of the Alzheimer type: A hypothesis. Neurobiol. Aging 1990, 11, 567-571. [CrossRef]

120. Aquilano, K.; Baldelli, S.; Ciriolo, M.R. Glutathione is a crucial guardian of protein integrity in the brain upon nitric oxide imbalance. Commun. Integr. Biol. 2011, 4, 477-479. [CrossRef] [PubMed]

121. Perluigi, M.; Di Domenico, F.; Giorgi, A.; Schinina, M.E.; Coccia, R.; Cini, C.; Bellia, F.; Cambria, M.T.; Cornelius, C.; Butterfield, D.A.; et al. Redox proteomics in aging rat brain: Involvement of mitochondrial reduced glutathione status and mitochondrial protein oxidation in the aging process. J. Neurosci. Res. 2010, 88, 3498-3507. [CrossRef] [PubMed]

122. Emir, U.E.; Raatz, S.; McPherson, S.; Hodges, J.S.; Torkelson, C.; Tawfik, P.; White, T.; Terpstra, M. Noninvasive quantification of ascorbate and glutathione concentration in the elderly human brain. NMR Biomed. 2011, 24, 888-894. [CrossRef] [PubMed]

123. Mandal, P.K.; Tripathi, M.; Sugunan, S. Brain oxidative stress: Detection and mapping of anti-oxidant marker 'Glutathione' in different brain regions of healthy male/female, $\mathrm{MCI}$ and Alzheimer patients using non-invasive magnetic resonance spectroscopy. Biochem. Biophys. Res. Commun. 2012, 417, 43-48. [CrossRef] [PubMed]

124. Gawryluk, J.W.; Wang, J.F.; Andreazza, A.C.; Shao, L.; Young, L.T. Decreased levels of glutathione, the major brain antioxidant, in post-mortem prefrontal cortex from patients with psychiatric disorders. Int. J. Neuropsychopharmacol. 2011, 14, 123-130. [CrossRef] [PubMed]

125. Chauhan, A.; Audhya, T.; Chauhan, V. Brain region-specific glutathione redox imbalance in autism. Neurochem. Res. 2012, 37, 1681-1689. [CrossRef] [PubMed]

126. Freitas, H.R.; Reis, R.A. Glutathione induces GABA release through P2X7R activation on Muller glia. Neurogenesis 2017, 4, e1283188. [CrossRef] [PubMed]

127. Faria, R.X.; Freitas, H.R.; Reis, R.A.M. P2X7 receptor large pore signaling in avian Muller glial cells. J. Bioenerg. Biomembr. 2017, 49, 215-229. [CrossRef] [PubMed]

128. Blaha, M.J.; Hung, R.K.; Dardari, Z.; Feldman, D.I.; Whelton, S.P.; Nasir, K.; Blumenthal, R.S.; Brawner, C.A.; Ehrman, J.K.; Keteyian, S.J.; et al. Age-dependent prognostic value of exercise capacity and derivation of fitness-associated biologic age. Heart 2016, 102, 431-437. [CrossRef] [PubMed]

129. Voss, M.W.; Nagamatsu, L.S.; Liu-Ambrose, T.; Kramer, A.F. Exercise, brain, and cognition across the life span. J. Appl. Physiol. 2011, 111, 1505-1513. [CrossRef] [PubMed]

130. Vijg, J.; de Grey, A.D. Innovating aging: Promises and pitfalls on the road to life extension. Gerontology 2014, 60, 373-380. [CrossRef] [PubMed]

131. Seals, D.R.; Justice, J.N.; LaRocca, T.J. Physiological geroscience: Targeting function to increase healthspan and achieve optimal longevity. J. Physiol. 2016, 594, 2001-2024. [CrossRef] [PubMed]

132. Di Benedetto, S.; Muller, L.; Wenger, E.; Duzel, S.; Pawelec, G. Contribution of neuroinflammation and immunity to brain aging and the mitigating effects of physical and cognitive interventions. Neurosci. Biobehav. Rev. 2017, 75, 114-128. [CrossRef] [PubMed]

133. Jackson, P.A.; Pialoux, V.; Corbett, D.; Drogos, L.; Erickson, K.I.; Eskes, G.A.; Poulin, M.J. Promoting brain health through exercise and diet in older adults: A physiological perspective. J. Physiol. 2016, 594, 4485-4498. [CrossRef] [PubMed]

134. Guure, C.B.; Ibrahim, N.A.; Adam, M.B.; Said, S.M. Impact of physical activity on cognitive decline, dementia, and its subtypes: meta-analysis of prospective studies. BioMed Res. Int. 2017, 2017, 9016924. [CrossRef] [PubMed] 
135. Bolduc, V.; Thorin-Trescases, N.; Thorin, E. Endothelium-dependent control of cerebrovascular functions through age: Exercise for healthy cerebrovascular aging. Am. J. Physiol. Heart Circ. Physiol. 2013, 305, H620-H633. [CrossRef] [PubMed]

136. De la Torre, R.; Corella, D.; Castaner, O.; Martinez-Gonzalez, M.A.; Salas-Salvador, J.; Vila, J.; Estruch, R.; Sorli, J.V.; Aros, F.; Fiol, M.; et al. Protective effect of homovanillyl alcohol on cardiovascular disease and total mortality: Virgin olive oil, wine, and catechol-methylathion. Am. J. Clin. Nutr. 2017, 105, 1297-1304. [CrossRef] [PubMed]

137. Ainslie, P.N.; Cotter, J.D.; George, K.P.; Lucas, S.; Murrell, C.; Shave, R.; Thomas, K.N.; Williams, M.J.; Atkinson, G. Elevation in cerebral blood flow velocity with aerobic fitness throughout healthy human ageing. J. Physiol. 2008, 586, 4005-4010. [CrossRef] [PubMed]

138. Xing, C.Y.; Tarumi, T.; Meijers, R.L.; Turner, M.; Repshas, J.; Xiong, L.; Ding, K.; Vongpatanasin, W.; Yuan, L.J.; Zhang, R. Arterial pressure, heart rate, and cerebral hemodynamics across the adult life span. Hypertension 2017, 69, 712-720. [CrossRef] [PubMed]

139. De la Torre, J.C. Cardiovascular risk factors promote brain hypoperfusion leading to cognitive decline and dementia. Cardiovasc. Psychiatry Neurol. 2012, 2012, 367516. [CrossRef] [PubMed]

140. Barnes, J.N. Exercise, cognitive function, and aging. Adv. Physiol. Educ. 2015, 39, 55-62. [CrossRef] [PubMed]

141. Viboolvorakul, S.; Patumraj, S. Exercise training could improve age-related changes in cerebral blood flow and capillary vascularity through the upregulation of VEGF and eNOS. BioMed Res. Int. 2014, 2014, 230791. [CrossRef] [PubMed]

142. Gertz, K.; Priller, J.; Kronenberg, G.; Fink, K.B.; Winter, B.; Schrock, H.; Ji, S.; Milosevic, M.; Harms, C.; Bohm, M.; et al. Physical activity improves long-term stroke outcome via endothelial nitric oxide synthase-dependent augmentation of neovascularization and cerebral blood flow. Circ. Res. 2006, 99, 1132-1140. [CrossRef] [PubMed]

143. Choi, D.H.; Lee, K.H.; Lee, J. Effect of exercise-induced neurogenesis on cognitive function deficit in a rat model of vascular dementia. Mol. Med. Rep. 2016, 13, 2981-2990. [CrossRef] [PubMed]

144. Pereira, A.C.; Huddleston, D.E.; Brickman, A.M.; Sosunov, A.A.; Hen, R.; McKhann, G.M.; Sloan, R.; Gage, F.H.; Brown, T.R.; Small, S.A. An in vivo correlate of exercise-induced neurogenesis in the adult dentate gyrus. Proc. Natl. Acad. Sci. USA 2007, 104, 5638-5643. [CrossRef] [PubMed]

145. Erickson, K.I.; Leckie, R.L.; Weinstein, A.M. Physical activity, fitness, and gray matter volume. Neurobiol. Aging 2014, 35 (Suppl. 2), S20-S28. [CrossRef] [PubMed]

146. Maass, A.; Duzel, S.; Goerke, M.; Becke, A.; Sobieray, U.; Neumann, K.; Lovden, M.; Lindenberger, U.; Backman, L.; Braun-Dullaeus, R.; et al. Vascular hippocampal plasticity after aerobic exercise in older adults. Mol. Psychiatry 2015, 20, 585-593. [CrossRef] [PubMed]

147. Hanning, U.; Roesler, A.; Peters, A.; Berger, K.; Baune, B.T. Structural brain changes and all-cause mortality in the elderly population-the mediating role of inflammation. Age 2016, 38, 455-464. [CrossRef] [PubMed]

148. Benedict, C.; Brooks, S.J.; Kullberg, J.; Nordenskjold, R.; Burgos, J.; Le Greves, M.; Kilander, L.; Larsson, E.M.; Johansson, L.; Ahlstrom, H.; et al. Association between physical activity and brain health in older adults. Neurobiol. Aging 2013, 34, 83-90. [CrossRef] [PubMed]

149. Erickson, K.I.; Prakash, R.S.; Voss, M.W.; Chaddock, L.; Hu, L.; Morris, K.S.; White, S.M.; Wojcicki, T.R.; McAuley, E.; Kramer, A.F. Aerobic fitness is associated with hippocampal volume in elderly humans. Hippocampus 2009, 19, 1030-1039. [CrossRef] [PubMed]

150. Morris, J.K.; Vidoni, E.D.; Johnson, D.K.; Van Sciver, A.; Mahnken, J.D.; Honea, R.A.; Wilkins, H.M.; Brooks, W.M.; Billinger, S.A.; Swerdlow, R.H.; et al. Aerobic exercise for Alzheimer's disease: A randomized controlled pilot trial. PLoS ONE 2017, 12, e0170547. [CrossRef] [PubMed]

151. Chaddock, L.; Erickson, K.I.; Prakash, R.S.; Kim, J.S.; Voss, M.W.; Vanpatter, M.; Pontifex, M.B.; Raine, L.B.; Konkel, A.; Hillman, C.H.; et al. A neuroimaging investigation of the association between aerobic fitness, hippocampal volume, and memory performance in preadolescent children. Brain Res. 2010, 1358, 172-183. [CrossRef] [PubMed]

152. Nyberg, J.; Aberg, M.A.; Schioler, L.; Nilsson, M.; Wallin, A.; Toren, K.; Kuhn, H.G. Cardiovascular and cognitive fitness at age 18 and risk of early-onset dementia. Brain 2014, 137, 1514-1523. [CrossRef] [PubMed]

153. Cahill, L. Why sex matters for neuroscience. Nat. Rev. Neurosci. 2006, 7, 477-484. [CrossRef] [PubMed] 
154. Taaffe, D.R.; Harris, T.B.; Ferrucci, L.; Rowe, J.; Seeman, T.E. Cross-sectional and prospective relationships of interleukin-6 and C-reactive protein with physical performance in elderly persons: MacArthur studies of successful aging. J. Gerontol. Ser. A Biol. Sci. Med. Sci. 2000, 55, M709-M715. [CrossRef]

155. De la Fuente, M.; Cruces, J.; Hernandez, O.; Ortega, E. Strategies to improve the functions and redox state of the immune system in aged subjects. Curr. Pharm. Des. 2011, 17, 3966-3993. [CrossRef] [PubMed]

156. Vassilaki, M.; Cha, R.H.; Aakre, J.A.; Therneau, T.M.; Geda, Y.E.; Mielke, M.M.; Knopman, D.S.; Petersen, R.C.; Roberts, R.O. Mortality in mild cognitive impairment varies by subtype, sex, and lifestyle factors: The Mayo Clinic Study of Aging. J. Alzheimer Dis. 2015, 45, 1237-1245. [CrossRef]

157. Xing, C.Y.; Tarumi, T.; Liu, J.; Zhang, Y.; Turner, M.; Riley, J.; Tinajero, C.D.; Yuan, L.J.; Zhang, R. Distribution of cardiac output to the brain across the adult lifespan. J. Cereb. Blood Flow Metab. 2017, 37, 2848-2856. [CrossRef] [PubMed]

158. Berchtold, N.C.; Cribbs, D.H.; Coleman, P.D.; Rogers, J.; Head, E.; Kim, R.; Beach, T.; Miller, C.; Troncoso, J.; Trojanowski, J.Q.; et al. Gene expression changes in the course of normal brain aging are sexually dimorphic. Proc. Natl. Acad. Sci. USA 2008, 105, 15605-15610. [CrossRef] [PubMed]

159. Brown, B.M.; Peiffer, J.J.; Martins, R.N. Multiple effects of physical activity on molecular and cognitive signs of brain aging: Can exercise slow neurodegeneration and delay Alzheimer's disease? Mol. Psychiatry 2013, 18, 864-874. [CrossRef] [PubMed]

160. Varma, V.R.; Chuang, Y.F.; Harris, G.C.; Tan, E.J.; Carlson, M.C. Low-intensity daily walking activity is associated with hippocampal volume in older adults. Hippocampus 2015, 25, 605-615. [CrossRef] [PubMed]

161. Pentikainen, H.; Ngandu, T.; Liu, Y.; Savonen, K.; Komulainen, P.; Hallikainen, M.; Kivipelto, M.; Rauramaa, R.; Soininen, H. Cardiorespiratory fitness and brain volumes in men and women in the FINGER study. Age Ageing 2017, 46, 310-313. [CrossRef] [PubMed]

162. Talbot, K. Brain insulin resistance in Alzheimer's disease and its potential treatment with GLP-1 analogs. Neurodegener. Dis. Manag. 2014, 4, 31-40. [CrossRef] [PubMed]

163. Akintola, A.A.; van Heemst, D. Insulin, aging, and the brain: Mechanisms and implications. Front. Endocrinol. 2015, 6, 13. [CrossRef] [PubMed]

164. Paolisso, G.; Gambardella, A.; Ammendola, S.; D'Amore, A.; Balbi, V.; Varricchio, M.; D’Onofrio, F. Glucose tolerance and insulin action in healty centenarians. Am. J. Physiol. 1996, 270, E890-E894. [PubMed]

165. Bertram, S.; Brixius, K.; Brinkmann, C. Exercise for the diabetic brain: How physical training may help prevent dementia and Alzheimer's disease in T2DM patients. Endocrine 2016, 53, 350-363. [CrossRef] [PubMed]

166. Claxton, A.; Baker, L.D.; Hanson, A.; Trittschuh, E.H.; Cholerton, B.; Morgan, A.; Callaghan, M.; Arbuckle, M.; Behl, C.; Craft, S. Long-acting intranasal insulin detemir improves cognition for adults with mild cognitive impairment or early-stage Alzheimer's disease dementia. J. Alzheimer Dis. 2015, 44, 897-906. [CrossRef]

167. Craft, S.; Claxton, A.; Baker, L.D.; Hanson, A.J.; Cholerton, B.; Trittschuh, E.H.; Dahl, D.; Caulder, E.; Neth, B.; Montine, T.J.; et al. Effects of Regular and Long-Acting Insulin on Cognition and Alzheimer's Disease Biomarkers: A Pilot Clinical Trial. J. Alzheimer Dis. 2017, 57, 1325-1334. [CrossRef] [PubMed]

168. Reger, M.A.; Watson, G.S.; Green, P.S.; Wilkinson, C.W.; Baker, L.D.; Cholerton, B.; Fishel, M.A.; Plymate, S.R.; Breitner, J.C.; DeGroodt, W.; et al. Intranasal insulin improves cognition and modulates beta-amyloid in early AD. Neurology 2008, 70, 440-448. [CrossRef] [PubMed]

169. Hoene, M.; Lehmann, R.; Hennige, A.M.; Pohl, A.K.; Haring, H.U.; Schleicher, E.D.; Weigert, C. Acute regulation of metabolic genes and insulin receptor substrates in the liver of mice by one single bout of treadmill exercise. J. Physiol. 2009, 587, 241-252. [CrossRef] [PubMed]

170. Castro, M.G.; Venutolo, C.; Yau, P.L.; Convit, A. Fitness, insulin sensitivity, and frontal lobe integrity in adults with overweight and obesity. Obesity 2016, 24, 1283-1289. [CrossRef] [PubMed]

171. Kang, E.B.; Cho, J.Y. Effects of treadmill exercise on brain insulin signaling and beta-amyloid in intracerebroventricular streptozotocin induced-memory impairment in rats. J. Exerc. Nutr. Biochem. 2014, 18, 89-96. [CrossRef] [PubMed]

172. Muller, A.P.; Gnoatto, J.; Moreira, J.D.; Zimmer, E.R.; Haas, C.B.; Lulhier, F.; Perry, M.L.; Souza, D.O.; Torres-Aleman, I.; Portela, L.V. Exercise increases insulin signaling in the hippocampus: Physiological effects and pharmacological impact of intracerebroventricular insulin administration in mice. Hippocampus 2011, 21, 1082-1092. [CrossRef] [PubMed] 
173. Zhang, H.; Zhang, C. Adipose "talks" to distant organs to regulate insulin sensitivity and vascular function. Obesity 2010, 18, 2071-2076. [CrossRef] [PubMed]

174. Ringseis, R.; Eder, K.; Mooren, F.C.; Kruger, K. Metabolic signals and innate immune activation in obesity and exercise. Exerc. Immunol. Rev. 2015, 21, 58-68. [PubMed]

175. Khoo, J.; Dhamodaran, S.; Chen, D.D.; Yap, S.Y.; Chen, R.Y.; Tian, R.H. Exercise-induced weight loss is more effective than dieting for improving adipokine profile, insulin resistance, and inflammation in obese men. Int. J. Sport Nutr. Exerc. Metab. 2015, 25, 566-575. [CrossRef] [PubMed]

176. Lowndes, J.; Zoeller, R.F.; Kyriazis, G.E.; Miles, M.P.; Seip, R.L.; Moyna, N.M.; Visich, P.; Pescatello, L.; Gordon, P.; Thompson, P.D.; et al. Hyperleptinemia is associated with CRP, but not apolipoprotein E, and is reduced by exercise training. Int. J. Sport Nutr. Exerc. Metab. 2014, 24, 524-531. [CrossRef] [PubMed]

177. Markofski, M.M.; Carrillo, A.E.; Timmerman, K.L.; Jennings, K.; Coen, P.M.; Pence, B.D.; Flynn, M.G. Exercise training modifies ghrelin and adiponectin concentrations and is related to inflammation in older adults. J. Gerontol. Ser. A Biol. Sci. Med. Sci. 2014, 69, 675-681. [CrossRef] [PubMed]

178. Yau, S.Y.; Li, A.; Hoo, R.L.; Ching, Y.P.; Christie, B.R.; Lee, T.M.; Xu, A.; So, K.F. Physical exercise-induced hippocampal neurogenesis and antidepressant effects are mediated by the adipocyte hormone adiponectin. Proc. Natl. Acad. Sci. USA 2014, 111, 15810-15815. [CrossRef] [PubMed]

179. Vella, C.A.; Allison, M.A.; Cushman, M.; Jenny, N.S.; Miles, M.P.; Larsen, B.; Lakoski, S.G.; Michos, E.D.; Blaha, M.J. Physical Activity and Adiposity-related Inflammation: The MESA. Med. Sci. Sports Exerc. 2017, 49, 915-921. [CrossRef] [PubMed]

180. Ogawa, K.; Sanada, K.; Machida, S.; Okutsu, M.; Suzuki, K. Resistance exercise training-induced muscle hypertrophy was associated with reduction of inflammatory markers in elderly women. Mediat. Inflamm. 2010, 2010, 171023. [CrossRef] [PubMed]

181. Santos, R.V.; Viana, V.A.; Boscolo, R.A.; Marques, V.G.; Santana, M.G.; Lira, F.S.; Tufik, S.; de Mello, M.T. Moderate exercise training modulates cytokine profile and sleep in elderly people. Cytokine 2012, 60, 731-735. [CrossRef] [PubMed]

182. Rodriguez-Miguelez, P.; Fernandez-Gonzalo, R.; Almar, M.; Mejias, Y.; Rivas, A.; de Paz, J.A.; Cuevas, M.J.; Gonzalez-Gallego, J. Role of Toll-like receptor 2 and 4 signaling pathways on the inflammatory response to resistance training in elderly subjects. Age 2014, 36, 9734. [CrossRef] [PubMed]

183. Chupel, M.U.; Direito, F.; Furtado, G.E.; Minuzzi, L.G.; Pedrosa, F.M.; Colado, J.C.; Ferreira, J.P.; Filaire, E.; Teixeira, A.M. Strength training decreases inflammation and increases cognition and physical fitness in older women with cognitive impairment. Front. Physiol. 2017, 8, 377. [CrossRef] [PubMed]

184. Braskie, M.N.; Boyle, C.P.; Rajagopalan, P.; Gutman, B.A.; Toga, A.W.; Raji, C.A.; Tracy, R.P.; Kuller, L.H.; Becker, J.T.; Lopez, O.L.; et al. Physical activity, inflammation, and volume of the aging brain. Neuroscience 2014, 273, 199-209. [CrossRef] [PubMed]

185. Chennaoui, M.; Gomez-Merino, D.; Drogou, C.; Geoffroy, H.; Dispersyn, G.; Langrume, C.; Ciret, S.; Gallopin, T.; Sauvet, F. Effects of exercise on brain and peripheral inflammatory biomarkers induced by total sleep deprivation in rats. J. Inflamm. 2015, 12, 56. [CrossRef] [PubMed]

186. Nieman, D.C.; Davis, J.M.; Brown, V.A.; Henson, D.A.; Dumke, C.L.; Utter, A.C.; Vinci, D.M.; Downs, M.F.; Smith, J.C.; Carson, J.; et al. Influence of carbohydrate ingestion on immune changes after $2 \mathrm{~h}$ of intensive resistance training. J. Appl. Physiol. 2004, 96, 1292-1298. [CrossRef] [PubMed]

187. Della Gatta, P.A.; Garnham, A.P.; Peake, J.M.; Cameron-Smith, D. Effect of exercise training on skeletal muscle cytokine expression in the elderly. Brain Behav. Immun. 2014, 39, 80-86. [CrossRef] [PubMed]

188. Piao, C.S.; Stoica, B.A.; Wu, J.; Sabirzhanov, B.; Zhao, Z.; Cabatbat, R.; Loane, D.J.; Faden, A.I. Late exercise reduces neuroinflammation and cognitive dysfunction after traumatic brain injury. Neurobiol. Dis. 2013, 54, 252-263. [CrossRef] [PubMed]

189. De la Torre, J.C. Are major dementias triggered by poor blood flow to the brain? Theoretical considerations. J. Alzheimer Dis. 2017, 57, 353-371. [CrossRef] [PubMed]

190. Pyo, J.O.; Yoo, S.M.; Ahn, H.H.; Nah, J.; Hong, S.H.; Kam, T.I.; Jung, S.; Jung, Y.K. Overexpression of Atg5 in mice activates autophagy and extends lifespan. Nat. Commun. 2013, 4, 2300. [CrossRef] [PubMed]

191. Mejias-Pena, Y.; Estebanez, B.; Rodriguez-Miguelez, P.; Fernandez-Gonzalo, R.; Almar, M.; de Paz, J.A.; Gonzalez-Gallego, J.; Cuevas, M.J. Impact of resistance training on the autophagy-inflammation-apoptosis crosstalk in elderly subjects. Aging 2017, 9, 408-418. [CrossRef] [PubMed] 
192. Mejias-Pena, Y.; Rodriguez-Miguelez, P.; Fernandez-Gonzalo, R.; Martinez-Florez, S.; Almar, M.; de Paz, J.A.; Cuevas, M.J.; Gonzalez-Gallego, J. Effects of aerobic training on markers of autophagy in the elderly. Age 2016, 38, 33. [CrossRef] [PubMed]

193. Marosi, K.; Bori, Z.; Hart, N.; Sarga, L.; Koltai, E.; Radak, Z.; Nyakas, C. Long-term exercise treatment reduces oxidative stress in the hippocampus of aging rats. Neuroscience 2012, 226, 21-28. [CrossRef] [PubMed]

194. Garcia-Mesa, Y.; Colie, S.; Corpas, R.; Cristofol, R.; Comellas, F.; Nebreda, A.R.; Gimenez-Llort, L.; Sanfeliu, C. Oxidative stress is a central target for physical exercise neuroprotection against pathological brain aging. J. Gerontol. Ser. A Biol. Sci. Med. Sci. 2016, 71, 40-49. [CrossRef] [PubMed]

195. Raefsky, S.M.; Mattson, M.P. Adaptive responses of neuronal mitochondria to bioenergetic challenges: Roles in neuroplasticity and disease resistance. Free Radic. Biol. Med. 2017, 102, 203-216. [CrossRef] [PubMed]

196. Marques-Aleixo, I.; Santos-Alves, E.; Balca, M.M.; Rizo-Roca, D.; Moreira, P.I.; Oliveira, P.J.; Magalhaes, J.; Ascensao, A. Physical exercise improves brain cortex and cerebellum mitochondrial bioenergetics and alters apoptotic, dynamic and auto(mito)phagy markers. Neuroscience 2015, 301, 480-495. [CrossRef] [PubMed]

197. Panati, K.; Suneetha, Y.; Narala, V.R. Irisin/FNDC5-An updated review. Eur. Rev. Med. Pharmacol. Sci. 2016, 20, 689-697. [PubMed]

198. Raschke, S.; Eckel, J. Adipo-myokines: Two sides of the same coin-Mediators of inflammation and mediators of exercise. Mediat. Inflamm. 2013, 2013, 320724. [CrossRef] [PubMed]

199. Dinoff, A.; Herrmann, N.; Swardfager, W.; Liu, C.S.; Sherman, C.; Chan, S.; Lanctot, K.L. The effect of exercise training on resting concentrations of peripheral brain-derived neurotrophic factor (BDNF): A Meta-Analysis. PLoS ONE 2016, 11, e0163037. [CrossRef] [PubMed]

200. Erickson, K.I.; Miller, D.L.; Roecklein, K.A. The aging hippocampus: Interactions between exercise, depression, and BDNF. Neuroscientist 2012, 18, 82-97. [CrossRef] [PubMed]

201. Rasmussen, P.; Brassard, P.; Adser, H.; Pedersen, M.V.; Leick, L.; Hart, E.; Secher, N.H.; Pedersen, B.K.; Pilegaard, H. Evidence for a release of brain-derived neurotrophic factor from the brain during exercise. Exp. Physiol. 2009, 94, 1062-1069. [CrossRef] [PubMed]

202. Wrann, C.D. FNDC5/irisin-Their role in the nervous system and as a mediator for beneficial effects of exercise on the brain. Brain Plast. 2015, 1, 55-61. [CrossRef] [PubMed]

203. Hashemi, M.S.; Ghaedi, K.; Salamian, A.; Karbalaie, K.; Emadi-Baygi, M.; Tanhaei, S.; Nasr-Esfahani, M.H.; Baharvand, H. Fndc5 knockdown significantly decreased neural differentiation rate of mouse embryonic stem cells. Neuroscience 2013, 231, 296-304. [CrossRef] [PubMed]

204. Warner, D.S.; Sheng, H.; Batinic-Haberle, I. Oxidants, antioxidants and the ischemic brain. J. Exp. Biol. 2004, 207, 3221-3231. [CrossRef] [PubMed]

205. Liu, J.; Atamna, H.; Kuratsune, H.; Ames, B.N. Delaying brain mitochondrial decay and aging with mitochondrial antioxidants and metabolites. Ann. N. Y. Acad. Sci. 2002, 959, 133-166. [CrossRef] [PubMed]

206. Gilgun-Sherki, Y.; Melamed, E.; Offen, D. Oxidative stress induced-neurodegenerative diseases: The need for antioxidants that penetrate the blood brain barrier. Neuropharmacology 2001, 40, 959-975. [CrossRef]

207. Slemmer, J.E.; Shacka, J.J.; Sweeney, M.I.; Weber, J.T. Antioxidants and free radical scavengers for the treatment of stroke, traumatic brain injury and aging. Curr. Med. Chem. 2008, 15, 404-414. [PubMed]

208. De Domenico, S.; Giudetti, A.M. Nutraceutical intervention in ageing brain. J. Gerontol. Geriatr. 2017, 65, 79-92.

(C) 2017 by the authors. Licensee MDPI, Basel, Switzerland. This article is an open access article distributed under the terms and conditions of the Creative Commons Attribution (CC BY) license (http:/ / creativecommons.org/licenses/by/4.0/). 